NBER WORKING PAPER SERIES

\title{
TAX-MOTIVATED TRADING BY INDIVIDUAL INVESTORS
}

\author{
Zoran Ivković \\ James Poterba \\ Scott Weisbenner \\ Working Paper 10275 \\ http://www.nber.org/papers/w10275
NATIONAL BUREAU OF ECONOMIC RESEARCH
1050 Massachusetts Avenue
Cambridge, MA 02138
January 2004

We thank an anonymous discount broker for providing data on individual investors' trades and Terry Odean for his help in obtaining and understanding the data set. Ivković and Weisbenner acknowledge the financial support from the College Research Board at the University of Illinois at Urbana-Champaign; Poterba thanks the National Science Foundation. We thank seminar participants at the American Economic Association Meetings, Chicago Graduate School of Business, University of Illinois, University of Michigan, University of Minnesota, and the NBER Public Economics Meetings for useful comments. All remaining errors are our sole responsibility. The views expressed herein are those of the authors and not necessarily those of the National Bureau of Economic Research.

(C2004 by Zoran Ivković, James Poterba, and Scott Weisbenner. All rights reserved. Short sections of text, not to exceed two paragraphs, may be quoted without explicit permission provided that full credit, including (C) notice, is given to the source. 
Tax-Motivated Trading by Individual Investors

Zoran Ivković, James Poterba, and Scott Weisbenner

NBER Working Paper No. 10275

January 2004

JEL No. H24, H31

\section{ABSTRACT}

We use data on the stock trades of a large number of individual investors to study how tax incentives affect the realization of capital gains and losses. We compare investors' realizations in their taxable and tax-deferred accounts, which allows us to identify tax-motivated trading. We reach three conclusions. First, we find a strong lock-in effect for capital gains in taxable accounts relative to tax-deferred accounts. The capital gains lock-in effect is stronger for large than for small transactions, and it intensifies at longer holding periods. Second, we find tax-loss selling throughout the calendar year, though it is most pronounced in December, particularly if the investor has realized capital gains elsewhere in the portfolio during the year. Third, we observe substantial heterogeneity in individual investors' propensity to trade. Controlling for this heterogeneity, however, does not alter the relationship between a stock's past performance and the realization decision.

Zoran Ivković

College of Business

University of Illinois

340 Wohlers Hall

1206 South Sixth Street

Champaign, IL 61820

ivkovich@uiuc.edu

James Poterba

Department of Economics

MIT, E52-350

50 Memorial Drive

Cambridge, MA 02142-1347

and NBER

poterba@mit.edu
Scott Weisbenner

College of Business

University of Illinois

340 Wohlers Hall

1206 South Sixth Street

Champaign, IL 61820

and NBER

weisbenn@uiuc.edu 
The realization-based capital gains tax in the United States presents investors with important opportunities for tax management. Constantinides (1984) demonstrates that investors can raise the after-tax return on their investments if they realize their losses while deferring the realization of capital gains. Many other studies, such as Ritter (1988), Poterba and Weisbenner (2001), and Grinblatt and Moskowitz (2004), note that taxpayers with accrued capital losses have an incentive to realize these losses before the end of the tax year and thereby to reduce their income tax liability. Year-end tax-loss selling is often cited as one of the contributing factors in the unusual behavior of stock returns in late December and early January.

While there is no general theory of why investors trade assets, a number of recent empirical studies, notably Odean (1998), Barber and Odean (2000, 2001, 2004) and Grinblatt and Keloharju (2001), have shown that asset and household characteristics are related to trading probabilities. These studies often suggest that investor behavior is inconsistent with the predictions of simple models of tax-efficient behavior in a world of serially uncorrelated asset returns. Rather than realizing losses and deferring gains, these studies suggest that investors are more likely to realize gains than to realize losses. This phenomenon was labeled the "disposition effect" by Shefrin and Statman (1985). They attributed it to investor unwillingness to dispose of assets that had declined in value, thereby admitting to themselves and others that their investment insight had failed, and to investor willingness to sell appreciated assets, thereby avoiding the regret associated with watching a one-time winning investment turn into a loss. This hypothesis about investor behavior, which derives from Kahnemann and Tversky's (1979) discussion of prospect theory, represents an important tenet of the emerging field of behavioral finance. Recent work on the disposition effect, such as Strobl (2003), has begun to explore optimal asset trading rules if asset returns exhibit serial dependence, to see whether observed patterns may be consistent with tax-efficient investor behavior.

The finding that many investors sell appreciated securities, rather than securities with losses, stands in contrast to a number of studies in public finance that suggest that capital gain realizations are inversely related to the capital gains tax rate. This literature, started by Feldstein, Slemrod, and Yitzhaki (1980) and surveyed in Poterba (2002), relies on data from individual tax returns. Tax returns track the outcome of investor trades, but they contain no information on the portfolio of assets that individuals could have traded. This makes it difficult to investigate how taxation or other factors affect the decision to realize gains or losses within a portfolio. The findings in this literature are not necessarily inconsistent with evidence of a disposition effect, because gain realizations could decline when tax rates rise even if gains are more likely to be realized than losses. Nevertheless, the tax 
return findings suggest that at least some taxpayers are responsive to tax considerations, while studies that report a disposition effect appear to contradict predictions of tax-efficient trading.

In this paper, we use a detailed data set on the investments made by a sample of individual investors at a large discount brokerage house in the United States between 1991 to 1996 to investigate several issues related to capital gains taxation and investor behavior. We evaluate taxinduced lock-in effects by comparing trading behavior in taxable and tax-deferred accounts. We provide new evidence on the determinants of end-of-year tax-loss trading. We investigate whether "wash sale" restrictions that prevent investors from claiming tax losses if they repurchase a security within thirty days of realizing a loss have a detectable impact on portfolio decisions.

Because we observe many stock purchases by the same investor, we can allow for individual heterogeneity in asset realization rates, while also controlling for the effects of asset returns, turn-ofthe-year effects, and other factors that may affect stock trading. The ability to control for investor heterogeneity in our econometric modeling allows us to test whether the relation between stock sales and past performance simply reflects differences across investors, with some investors just happening to sell more often than others and also achieving different returns, or whether it reflects behavioral differences for most investors associated with asset returns.

A central focus of our analysis is the comparison of trading behavior in taxable and taxdeferred accounts. Since we observe many individuals with stock investments in both settings, we can control for individual heterogeneity in trading propensities and focus on how the tax differences between these accounts affects behavior. The disposition effect predicts a positive relation between realization probabilities and past returns, while tax considerations predict a negative relation. Under the assumption that the disposition effect has the same impact on investments held in taxable and tax-deferred accounts, comparing the trading probabilities in the two provides a means to identify the magnitude of tax-motivated trading. The disposition effect should be evident in trading behavior in both taxable and tax-deferred accounts, but the effect of taxation on trading decisions should only emerge in taxable accounts.

This comparison suggests that, for stock purchases worth at least $\$ 10,000$, the probability of selling appreciated stock in taxable accounts falls below the probability for similar stocks in tax-deferred accounts, particularly after the stock has been held for a few months. For example, a capital gain of $25 \%$ is associated with a $22 \%$ increase in the monthly hazard rate of selling stock in a taxable account during the first six months after purchase, compared with a $28 \%$ increase in tax-deferred accounts. Conditional on having held the stock for one year, a $25 \%$ capital gain is associated with a $6 \%$ reduction in monthly hazard rates in a taxable account, 
while there is no relation between past gains and selling probabilities in a tax-deferred account. Conditional on being held a year, the probability that a stock with an accrued capital gain is sold within five years of purchase is 16 percentage points lower if the stock is in a taxable account than if it is in a tax-deferred account. Investors are particularly reluctant to sell stocks with gains in taxable accounts relative to tax-deferred accounts during the month of December. This is consistent with trying to postpone tax liabilities into the next tax year.

Along with Odean (1998), Barber and Odean (2004), and many other studies in the "January effect" literature, we find that individual investors are more apt to sell losers than winners in taxable accounts in December. This pattern is known as "year-end tax-loss selling." Unlike Odean (1998) and Barber and Odean (2004), however, we consider the role of holding period differences as well as investor attributes that may affect loss realization, and thereby offer new insights on the motivation for December trades. We reach three novel conclusions. First, December tax-loss selling is particularly strong for stocks that qualify for short-term loss treatment and hence generate larger tax savings for investors. The realization of short-term losses in December increased when the differential between short-term and long-term capital gains tax rates increased in the 1993 Omnibus Budget Reconciliation Act. Second, tax-loss selling increases when the overall market is doing well or when the investor has realized gains, and thus the demand for loss offsets is likely to be high. This suggests that activity elsewhere in the portfolio affects a household's decision to sell a particular stock. Third, by comparing realizations in taxable and tax-deferred accounts we find evidence of tax-loss selling in all months, though the effect is less pronounced than that in December. For example, a 25\% loss is associated with an $11 \%$ higher monthly realization probability in a taxable account, relative to tax-deferred account, in months other than December, while the increase is $81 \%$ in December.

Finally, we are not aware of any previous research on the U.S. capital gains tax that has considered how wash sale rules affect individual trading decisions. We find that the probability that a stock will be repurchased within thirty days, if it is sold at a loss in December, is lower than the probability of such a repurchase following sales in other months. We focus on December loss sales because our earlier findings suggest that they are particularly likely to be tax-motivated. This pattern is consistent with wash-sale rules affecting individual investors' trading activity. However, individuals who realize losses in taxable accounts in months other than December are about as likely to repurchase the same security within thirty days as investors who sell depreciated stock in tax-deferred accounts are, even though the latter transaction would not "poison" a potential tax loss. 
The paper is divided into four sections. In Section I, we describe our data set and present summary information on trading probabilities and holding periods for common stocks. Section II presents empirical evidence on the probability of selling individual stocks as a function of holding period return and calendar month. Section III examines the role of wash sale restrictions and presents modest evidence that these restrictions affect investor behavior. Section IV summarizes our findings and discusses how to evaluate the relative numbers of, and market impact of, tax-wise and tax-oblivious investors.

\section{Data Description and Summary}

We analyze a data set, obtained from a large discount brokerage house, of individual investors' monthly positions and trades over a six-year period from 1991 to 1996 . It covers all the investments 78,000 households made through the brokerage house, ranging from common stocks, mutual funds, government and corporate bonds, foreign securities, to derivatives. Each household has at least one account, but some have many. The maximum is twenty-one and the median is two. Nearly 30,000 households have both taxable accounts and tax-deferred accounts, which are either IRAs or Keogh plans. The data set does not cover tax-deferred accounts provided through work such as 401(k)-type plans. For a detailed description of the data set see Barber and Odean (2000).

We focus on trades of common stocks. These investments constitute nearly two thirds of the total value of household investments in the sample. We use the Center for Research in Security Prices (CRSP) database to obtain information on stock returns. We are particularly interested in stock trades made by the households that had both taxable and tax-deferred accounts. This sample criterion ensures that any differences in trading activity between taxable and tax-deferred accounts will not be driven by differences in the type of investors in taxable and tax-deferred accounts, as-by construction they are the same in our sample. Of all such stock trades, we considered all purchases that did not have matching sales in the sample period, as well as the purchases and the sales that we could match unambiguously. Examples of trades that we could not match unambiguously include sales that do not have a preceding purchase by the same household earlier during the sample period, as well as sales that are preceded by multiple purchases. When multiple sales follow a single purchase, we include only the first sale in our data sample. For example, if an investor bought 1,000 shares of Microsoft in June 1991, and sold 500 shares in January 1993, we would treat this as a sale of the stock position. This means that our analysis may understate the actual holding period for some common stock investments. However, the circumstances described in the example are unusual: ninety-three percent of the sales in our sample liquidate the investor's full position. 


\section{A. Summary Statistics}

Table 1 presents summary information on the number of stock purchases, stock sales, and the dollar values of such trades for different years in our sample. Applying the criteria outlined above resulted in 414,047 purchases during the sample period, representing 23,877 different households. We often restrict the sample to the 97,266 stock purchases of $\$ 10,000$ or more. These represent 23 percent of all purchases, but nearly two-thirds of the dollar-weighted purchases. Just below threefifths of all stock purchases, and two thirds of those valued at more than $\$ 10,000$, were executed in taxable accounts, with the balance executed in tax-deferred accounts. Fifty-two percent of all purchases, and 60 percent on a value-weighted basis, were followed by sales before the end of our sample on November 30, 1996.

We focus on the interaction between holding period, accrued gain or loss, and the sale probability for each stock position. Our approach differs from Odean's (1998) focus on the "proportion of gains realized" and the "proportion of losses realized" in various calendar months. These proportions aggregate positions held for many different holding periods and are thus not suited to address holding period dependence in the disposition effect. Our richer empirical framework allows for interactions between holding period returns, calendar months, and tax status.

One of the potential concerns about this data set is that it may be unrepresentative of the broader individual investor population because a low-cost discount broker might attract high-trading investors. The IRS periodically publishes the distribution of the holding period of sales of corporate stock reported on individual tax returns. Specifically, Auten and Wilson (1999), Wilson (2002), and Wilson (2003) report Sales of Capital Assets (SOCA) data for 1985, 1997, 1998, and 1999. IRS data on the realization of all capital gains and losses on corporate stock in taxable accounts enable us to make some comparisons with realization patterns in this data set.

The summary statistics from the IRS data are quite similar to those from this data set. Specifically, the left section of Panel A in Table 2 reports the distribution of stock sales by holding period, focusing on stock held at most four years, for the four years the IRS has made SOCA data available. Strikingly, the reported holding periods of stocks sold display a rapid decline, similar to the baseline hazard functions we will estimate in Section II, with more stocks sold in 1998 and 1999 with a holding period of one month or less than with a holding period of one to four years. The percentage of stocks sold that has been held one month or less has increased steadily over the period, rising from $14 \%$ in 1985 to $21 \%$ in 1997 to $35 \%$ in 1999. Similarly, the fraction of stock sold with a holding period of one to four years has fallen from $47 \%$ in 1985 to $29 \%$ in 1997 to $23 \%$ in 1999 . 
To compare the IRS data with our brokerage house data, we focus on stock sales during 1995, the last full year in our sample. We focus on sales in 1995 that we can link back to the original purchase. Since the data set starts in 1991, that means we can trace back sales to their original purchase as long as the holding period is at most four years. The right section of Panel A in Table 2 reports the distribution of stock sales by holding period, again focusing on stocks held at most four years, for sales in taxable accounts during 1995 in the brokerage house data. The most directly comparable published IRS data, both in terms of closeness in date as well as closeness in stock market environment, are the data for 1997. The return on S\&P 500 was 38\% in 1995 and 33\% in 1997. The distributions of holding periods are remarkably similar. The percentage of stocks sold with a holding period of one month or less is $21 \%$ in both data sets and the proportion of sales with a holding period of one to four years is remarkably close: $29 \%$ in the IRS data and $30 \%$ in the brokerage house data. The distribution of sales of stocks originally purchased for $\$ 10,000$ or more, the sample of "large" purchases on which we will later focus attention, features more sales with shorter holding periods relative to sales with longer holding periods. This result foreshadows the stronger capital gain lock-in effect we will report for larger purchases.

Finally, Panel B of Table 2 reports the distribution of stock sales by both holding period and calendar month of the sale, disaggregated by whether the stock had a capital gain or capital loss when it was sold. The distributions for gains and losses reported on tax returns in 1997 are very similar to the respective distributions for gains and losses recorded in the brokerage house data in 1995. The percentage of sales in December is also similar in the two data sets. Indeed, $16.9 \%$ of realizations of losses occur in December in the brokerage house data, compared to $14.2 \%$ of loss realizations reported on tax returns, whereas December realizations of gains represent $6.6 \%$ and $8.4 \%$ of gain realizations, respectively. While the IRS data are useful for benchmarking how representative the trading activities of customers of the brokerage house are of the general individual investor, they cannot be used to study how the probability of realization depends on the stock's gain or loss. Any such analysis requires a data set like ours that records the timing of stock purchases as well as sales.

\section{B. Graphical Summary of Holding Periods and Trading Probabilities}

We begin our analysis of how stock appreciation or depreciation affects realization probabilities by calculating hazard functions for the probability of selling stock. Figure 1 reports the hazard rate - the probability of sale in a given month conditional on holding the stock until that point — for holding periods between one and 36 months. The figure shows the hazard rate for all stock purchases in taxable accounts (the dashed line), as well as the hazard for all stocks in taxable 
accounts that experienced a gain between their date of purchase and the beginning of the specified month (full black line), and all stocks that experienced a loss (full gray line). We focus on stocks purchased during January, so turn-of-the-year trading will be reflected in months 12, 24, and 36 after purchase. We array the data so that each stock purchase is indexed by $i$, and we consider the probability that position $\mathrm{i}$ is liquidated $\mathrm{t}$ months after purchase, conditional on not having been sold until that date. The hazard functions in this case are linear probability models of the form

$$
\operatorname{SELL}_{\mathrm{i}, \mathrm{t}}=\alpha_{\mathrm{t}}+\beta_{1, \mathrm{t}} * \mathrm{I}(\mathrm{GAIN})_{\mathrm{i}, \mathrm{t}-1}+\beta_{2, \mathrm{t}} * \mathrm{I}(\operatorname{LOSS})_{\mathrm{i}, \mathrm{t}-1}+\varepsilon_{\mathrm{i}, \mathrm{t}}
$$

where $\mathrm{I}(\mathrm{GAIN})_{\mathrm{i}, \mathrm{t}-1}$ and $\mathrm{I}(\mathrm{LOSS})_{\mathrm{i}, \mathrm{t}-\mathrm{l}}$ are indicator variables for stocks that have experienced an increase or decrease in price since the date of purchase, respectively.

$\mathrm{SELL}_{\mathrm{i}, \mathrm{t}}$ is an indicator variable set to unity if stock position $\mathrm{i}$ is liquidated $\mathrm{t}$ months after it was purchased, and set to zero otherwise. The specification allows for differential hazard rates for stocks with losses and gains. The constant term, $\alpha_{t}$, represents the baseline hazard probability that the stock will be sold $\mathrm{t}$ months after it was purchased, conditional on having not been sold previously and having zero capital appreciation at the start of month $t$. The hazard rate for selling a stock $t$ months after purchase if the stock has a gain is $\alpha_{t}+\beta_{1, t}$, while the hazard rate for a stock with a loss is $\alpha_{t}+\beta_{2, t}$. Because we only observe the stock return since purchase starting with the second month after purchase, we assign the unconditional probability of sale in month one to both gains and losses.

Figure 1 shows that the hazard rate for stock sale in the taxable account drops quickly in the first six months after the date of purchase. The hazard rate is fifteen percent during the first month, but it drops to less than five percent per month after six months and continues to decline at longer holding periods, falling to less than $2 \%$ per month after 18 months. This pattern is observed both for stocks with gains and for stocks with losses. At most holding periods, the hazard rate for stocks with gains is higher than that for stocks with losses. Figure 2 presents analogous information for stock purchases of at least $\$ 10,000$, adding hazard rates for stocks with gains and losses in tax-deferred accounts. This sample of large purchases in taxable accounts is likely to be more affected by taxrelated motivations for sale, as the tax consequence of a trade is higher given the increased value. The exponential decline in hazard rates is the same as that in Figure 1, although the hazard rates for the first months after purchase are significantly higher than that for the whole sample. Figure 2 presents our first evidence of the capital gains lock-in effect, as after the first few months the probability of a realization of a gain in a taxable account falls below that in a tax-deferred account.

To facilitate the interpretation of this information on selling patterns, Figure 3 reports the cumulative probability that an investor who purchases stock in a taxable account will sell that stock 
by various holding periods. If $h(t)$ denotes the hazard rate in month $\mathrm{t}$, the probability that the stock is still held at the end of month $\mathrm{t}$ is $\prod_{\mathrm{s}=1, \mathrm{t}}(1-\mathrm{h}(\mathrm{s}))$. The probability that the stock is sold in month $\mathrm{t}$ is $h(t) * \prod_{s=1, t-1}(1-h(s))$. The two solid lines present sale probabilities calculated for all positions in the sample, while the two dashed lines correspond to the positions for which the investor's initial purchase was at least $\$ 10,000$. The cumulative probability of sale is calculated from the hazard function estimates for each month up to the given holding period.

Figure 3 suggests several conclusions. First, cumulative sale probabilities rise rapidly in the months just after purchase, but flatten out soon thereafter. By six months after purchase, roughly two-fifths of stocks have been sold, by one year after the date of purchase nearly one-half of all stocks have been sold, and by three years after purchase nearly two-thirds have been sold. This is indicative of the reduced likelihood of sale in a given month as the holding period increases. Second, sale probabilities for stocks with gains are higher than the corresponding probabilities for stocks with losses, both in the entire sample and in the sample of large purchases. This can be seen by comparing the lines with the same pattern, but different colors, in the figure. By one year after the date of purchase, the probability that the stock has been sold is more than 50 percent if the stock had a capital gain at the beginning of every month since the time of purchase. The probability is lower, 44 percent, if the share had a loss at the beginning of every month since purchase. This confirms Odean's (1998) "disposition effect” findings. Finally, sale probabilities are marginally higher for the sample of large stock purchases than for the entire sample. At the twenty-four month horizon, the cumulative sale probability for a stock that never closed at a loss at the end of any month, and with an initial \$10,000 purchase, is 69 percent, compared with 63 percent for the sample of all purchases.

If the realization-based capital gains tax discourages investors from selling appreciated securities and encourages them to realize losses, then we should see differences in the cumulative sale probabilities between taxable and tax-deferred accounts for stock purchases with both subsequent gains and subsequent losses. To that end, Figure 4 reports the differences between cumulative sale probabilities for stocks held in different types of accounts. The solid black line is the differential cumulative sale probability for stocks that have had gains at the beginning of every month since the date of purchase and the dashed black line is the analogous plot for stock purchases of more than $\$ 10,000$. For large stock purchases, the sale probability after two years is eight percent lower in taxable than in tax-deferred accounts, as capital gains tax "lock-in" would predict.

The solid gray line in Figure 4, which corresponds to all purchases, and the dashed gray line, which corresponds to purchases in excess of $\$ 10,000$, are the differentials between the cumulative 
sale probabilities in taxable and tax-deferred accounts for stocks that had experienced losses at the beginning of each of the months since purchase. The probability of realizing losses is higher in taxable accounts than it is in tax-deferred accounts, and Figure 4 offers some evidence that the difference between the sale probabilities in taxable and tax-deferred accounts declines with the size of the purchase.

The disparities in cumulative holding periods for stocks with gains and losses suggest a more detailed analysis of the monthly holding periods for stocks. We next estimate a number of regressions of the form:

$$
\operatorname{SELL}_{\mathrm{i}, \mathrm{t}}=\alpha_{\mathrm{t}}+\beta_{1, \mathrm{t}} * \mathrm{GAIN}_{\mathrm{i}, \mathrm{t}-1}+\beta_{2, \mathrm{t}} * \operatorname{LOSS}_{\mathrm{i}, \mathrm{t}-1}+\varepsilon_{\mathrm{i}, \mathrm{t}}
$$

where $\operatorname{GAIN}_{\mathrm{i}, \mathrm{t}-1}=\max \left(\operatorname{Return}_{\mathrm{i}, \mathrm{t}-1}, 0\right)$, and $\operatorname{LOSS}_{\mathrm{i}, \mathrm{t}-1}=\min \left(\operatorname{Return}_{\mathrm{i}, \mathrm{t}-1}, 0\right)$. As before, $\mathrm{SELL}_{\mathrm{i}, \mathrm{t}}$ is an indicator variable set to unity if stock position $\mathrm{i}$ is liquidated $\mathrm{t}$ months after it was purchased, and is set to zero otherwise. Note that, under these definitions, GAIN is non-negative and LOSS is nonpositive. This implies that a positive coefficient on GAIN raises the probability of stock sale, while a negative coefficient on LOSS does the same. Once again, because we only observe the stock return since purchase starting with the second month after purchase, we assign the unconditional probability of sale in month one to both gains and losses. The resulting coefficient estimates for the sample of large purchases (i.e., purchases of $\$ 10,000$ or more) are shown in Table 3. Each regression is estimated using the sample of stock positions that were not liquidated until at least the holding period indicated in the first column of the table.

To summarize the results graphically, we focus on a hypothetical position that exhibits a gain of 25 percent since date of purchase at the end of every subsequent month, and a position that exhibits a loss of 25 percent in an analogous manner. Figure 5a shows that, for assets held in taxable accounts, the disposition effect is particularly clear in the first few months after the date of purchase. In the second month of ownership, for example, the probability of sale for a stock with a 25 percent gain is five percentage points higher than the analogous probability for a stock that has experienced no change in value (the leftmost black bar in the figure). The sale probability for a stock with a 25 percent loss is 2.4 percent lower than that for a stock with no price change (the leftmost white bar). By six months after the date of purchase, the differential sale probabilities that results from a gain or a loss are fairly small.

Figure $5 \mathrm{~b}$ contrasts the sale probability for stocks with 25 percent gains, and 25 percent losses, in taxable and tax-deferred accounts. The likelihood of selling a position with an unrealized gain of 25 percent is greater in the tax-deferred than it is in the taxable account, particularly for short 
holding periods. Moreover, the probability of selling a position with a loss is higher in the taxable than it is in the tax-deferred account. Thus, while there is a positive relation between returns and stock sales over holding periods less than a year (as shown in Figure 5a), it is less positive in taxable than in tax-deferred accounts (as shown in Figure 5b). This finding is consistent with tax motivations to realize losses and to defer realizations of gains for stocks held in taxable accounts, but not for those held in tax-deferred accounts.

Taken together, the selling patterns in Figures 1 through 5 suggest that taxable investors are deterred from realizing gains by the presence of realization-based capital gains taxes. Previous research suggests that loss realization behavior may be different at the end of the calendar year than at other times. Since our data allow us to track both the dates at which shares are sold and the holding period of the sales, we are able to confirm in unreported analyses that the realization of losses increases dramatically in December, particularly in the last week of December. Barber and Odean (2004) report a similar finding about year-end tax-loss selling when they contrast the proportion of gains realized and losses realized by calendar month in taxable and tax-deferred accounts. They find that the ratios for taxable and tax-deferred accounts are very similar in all months except December, when the ratio for taxable accounts drops dramatically while the ratio for tax-deferred accounts remains stable. Their findings suggest that tax-loss selling takes place in December, but, because their methodology does not allow the realization rate to vary with the holding period, it cannot assess the lock-in effect directly, nor can it disentangle the effects of asset price changes, holding period, and calendar month. By contrast, our econometric modeling is designed precisely to address these issues.

\section{Tax Incentives and Stock Sales}

To disentangle the contributory effects of calendar month, holding period, and embedded capital gains and losses on investor trading decisions, we estimate hazard models for stock sales in various circumstances using a variety of nonparametric and parametric models. Since investors in our data purchase seventeen stocks on average, and the median investor purchases nine stocks, over the six-year sample, we are able to control for household heterogeneity in the propensity to sell stock. We can therefore investigate the robustness of our findings on lock-in and disposition effects with respect to various approaches to modeling household heterogeneity. 


\section{A. Cox Proportional Hazards Models with Nonparametric Baseline Hazards}

We estimate a Cox proportional hazards model with GAIN, LOSS, and a range of indicator variables for the characteristics of the holding period as variables that shift the realization probability. The baseline hazard rate is estimated non-parametrically, following the methods of Han and Hausman (1990) and Meyer (1990). The proportional hazards specification assumes that the hazard function for the sale of stock purchase $i, t$ months after the purchase, takes the form

$$
h_{i}(t)=\gamma_{0}(t) * e^{X \beta i, t}
$$

where $\gamma_{0}(t)$ denotes the baseline hazard. We begin with a simple specification that focuses on the link between gains, losses, the end of the calendar year, and trading decisions:

$$
\begin{aligned}
\mathrm{X} \beta_{\mathrm{i}, \mathrm{t}}= & \beta_{1}{ }^{*} \operatorname{GAIN}_{\mathrm{i}, \mathrm{t}-1}+\beta_{2}{ }^{*} \operatorname{GAIN}_{\mathrm{i}, \mathrm{t}-1} * \text { December }_{\mathrm{i}, \mathrm{t}}+\beta_{3} * \operatorname{LOSS}_{\mathrm{i}, \mathrm{t}-1}+ \\
& \beta_{4}{ }^{*} \operatorname{LOSS}_{\mathrm{i}, \mathrm{t}-\mathrm{1}} * \text { December }_{\mathrm{i}, \mathrm{t}}+\beta_{5} * \text { December }_{\mathrm{i}, \mathrm{t}}+\varepsilon_{\mathrm{i}, \mathrm{t}}
\end{aligned}
$$

We report hazard function estimates for the full sample of stock purchases, but we focus most of our analysis on the sample of purchases with an initial value of more than $\$ 10,000$. The disposition effect predicts households will sell stocks with accrued gains and hold stocks with accrued losses. In terms of specification (4), this implies that $\beta_{1}>0$ and $\beta_{3}>0$. Tax-motivated trading predicts exactly the opposite-households will hold stocks with accrued gains and sell stocks with accrued losses. In terms of specification (4), this implies that $\beta_{1}<0$ and $\beta_{3}<0$. Further, a desire to postpone the realization of gains into the next tax year implies $\beta_{2}<0$ (i.e., investors are less apt to realize gains in December) and a desire to capture tax losses in the current calendar year implies $\beta_{4}<0$ (i.e., investors are more apt to realize losses in December). Thus, positive coefficients on GAIN and LOSS are consistent with the disposition effect dominating, while negative coefficients are consistent with tax motivations dominating.

We also report hazard models for taxable accounts as well as models for all accounts with an indicator variable and interaction terms to test for statistical differences between behavior in taxable and tax-deferred accounts. In this case, the specification becomes:

$$
\begin{aligned}
\mathrm{X} \beta_{\mathrm{i}, \mathrm{t}}= & \beta_{1}{ }^{*} \mathrm{GAIN}_{\mathrm{i}, \mathrm{t}-1}+\beta_{2} * \mathrm{GAIN}_{\mathrm{i}, \mathrm{t}-1} * \text { December }_{\mathrm{i}, \mathrm{t}}+\beta_{3} * \mathrm{LOSS}_{\mathrm{i}, \mathrm{t}-1}+ \\
& \beta_{4}{ }^{*} \operatorname{LOSS}_{\mathrm{i}, \mathrm{t}-1} * \text { December }_{\mathrm{i}, \mathrm{t}}+\beta_{5} * \text { December }_{\mathrm{i}, \mathrm{t}}+ \\
& \beta_{6}{ }^{*} \mathrm{GAIN}_{\mathrm{i}, \mathrm{t}-1} * \mathrm{TAX}_{\mathrm{i}}+\beta_{7} * \mathrm{GAIN}_{\mathrm{i}, \mathrm{t}-1} \text { December }_{\mathrm{i}, \mathrm{t}} * \mathrm{TAX}_{\mathrm{i}}+\beta_{8} * \mathrm{LOSS}_{\mathrm{i}, \mathrm{t}-1} * \mathrm{TAX}_{\mathrm{i}}+ \\
& \beta_{9}{ }^{*} \mathrm{LOSS}_{\mathrm{i}, \mathrm{t}-1} * \text { December }_{\mathrm{i}, \mathrm{t}} * \mathrm{TAX}_{\mathrm{i}}+\beta_{10} * \text { December }_{\mathrm{i}, \mathrm{t}} * \mathrm{TAX}_{\mathrm{i}}+\varepsilon_{\mathrm{i}, \mathrm{t}}
\end{aligned}
$$


where $\mathrm{TAX}_{\mathrm{i}}$ is an indicator variable for stock position $\mathrm{i}$ being held in a taxable account. The baseline hazard rates are estimated separately for taxable and tax-deferred accounts. In this specification, the disposition effect should be reflected in the coefficients $\beta_{1}$ through $\beta_{5}$, while the coefficients on the variables interacted with TAX will reflect the importance of tax-motivated trading. To the extent that psychological motivations like the disposition effect are more pronounced in taxable relative to tax-deferred accounts, the interaction terms of TAX with GAIN/LOSS will understate the magnitude of tax-motivated trading. Whether such motivations are different in different accounts is unclear. Barber and Odean (2004) present evidence that there is more trading in taxable accounts, which may indicate different perceptions of the two accounts.

Table 4 presents our hazard function estimates for both the full sample of all transactions (upper panel) as well as the sample of large purchases (bottom panel). The findings provide explicit confirmation for many of the effects that we observed in the figures. In particular, the coefficient on LOSS for taxable accounts is positive for the full sample and for the large-transaction sample, suggesting that in most months a larger loss leads to a lower probability of gain realization. The coefficient for the interaction term LOSS*December, however, is strongly negative, indicating that a loss in December is much more likely to be realized. The LOSS coefficient of 1.03 for the full sample implies that in non-December months the monthly hazard rate for a stock that has lost 25 percent of its value since the date of purchase is $23 \%$ lower than that for a stock with no price change (i.e., $\left.\mathrm{e}^{1.03 *(-0.25)}-1=-0.23\right)$. But, in December the stock with the accrued loss is 35 percent more likely to be sold than the stock with no price change (i.e., $\left.\mathrm{e}^{(1.03-2.23)^{*}(-0.25)}-1=0.35\right)$.

The results in Table 4 show that the coefficient on GAIN is positive for the sample of all transactions, but only one tenth as large as the LOSS coefficient for the sample of all purchases, and negative but statistically indistinguishable from zero for the large-transaction sample. This suggests that, particularly for smaller purchases, the disposition effect is more pronounced than tax-motivated trading and thus favorable returns make realizations more likely.

Table 4 also presents estimates of equation (5), which permits a comparison of the hazard model coefficients for taxable accounts and those for tax-deferred accounts. While there is little difference in the propensity to realize gains in taxable and tax-deferred accounts for the full sample of purchases, we do find evidence of a capital gains lock-in effect for larger purchases (coefficient estimate of -0.09), which is even stronger during the month of December (coefficient estimate of 0.22). The LOSS*December interaction is substantially smaller in tax-deferred accounts than it is in taxable accounts. This suggests that, as is generally accepted in the literature, that tax considerations 
may explain a substantial part of the year-end trading patterns. Further, by comparing realizations in taxable and tax-deferred accounts we find evidence of tax-loss selling in all months, though the effect is more muted in the non-December months. For example, a 25\% loss is associated with an 11 percent higher monthly hazard rate in taxable accounts relative to tax-deferred accounts in nonDecember months (i.e., $\left.\mathrm{e}^{-0.40^{*}(-0.25)}-1=0.11\right)$, consistent with a desire to realize a tax deduction, while the comparable boost in December is $81 \%$ (i.e., $\mathrm{e}^{(-0.40-1.97)^{*}(-0.25)}-1=0.81$ ). Comparable effects are found for losses on larger purchases. Controlling for returns, the trading rate in taxable accounts is higher in December than it is in other months.

One concern in modeling investors' trading decisions is the role of heterogeneity with respect to holding periods and trading risk. The Cox proportional hazards model, which allows for a general baseline hazard function $\lambda(t)$, can be generalized to allow for investor-specific $\lambda_{h}(t)$ functions. Gonul and Srinivasan (1993) provide an example of how investor heterogeneity in hazard models can be studied with repeat-spell data. Relatively few studies in economics, however, have estimated hazard models with repeat-spell data, so the estimation of household-specific baseline hazards is unusual.

The rightmost three columns of Table 4 incorporate investor-specific baseline hazard functions into the estimation. Our findings with investor-specific baselines for taxable accounts are very similar to those with a constrained baseline, although the coefficient on GAIN nearly doubles in size, and evidence for capital gains lock-in is somewhat stronger. The positive effect on GAIN is also observed for the large transaction sample: the statistically insignificant negative coefficient without investor-specific baselines becomes positive and statistically significant with investor effects. This suggests that, once we control for individual-specific sale rates, there is a more pronounced disposition effect, particularly in tax-deferred accounts. The disposition effect is still smaller for larger stock purchases than it is for the whole sample. The similarity of the other coefficients with and without investor specific baselines suggests that investor heterogeneity cannot explain the different findings for large and small stock purchases.

The sensitivity of our results from Table 4 to the size of the initial stock purchase leads us to estimate separate hazard models for stock purchases of various sizes. For example, the tax consequence of realizing a gain or loss for a stock purchase of $\$ 500$ is substantially less than that for $\$ 10,000$. Table 5 reports our findings. For taxable accounts, as well as for taxable accounts relative to tax-deferred accounts, the GAIN variable has a positive effect on sale probability for the smallest transactions, but this effect diminishes as the value of the stock position increases. Focusing on gains in taxable accounts, the disposition effect seems to outweigh tax motivations for all but the $\$ 10,000+$ 
purchases. When we compare transactions in taxable accounts to those in tax-deferred accounts, we find evidence of capital gains lock-in for purchases $\$ 5,000+$. For LOSS, the coefficient is positive for taxable accounts regardless of the size of the initial purchase. The table also shows that, when we compare taxable and tax-deferred accounts, a loss raises the sale probability by a larger margin for taxable purchases than it does for tax-deferred purchases of all sizes, but the strongest effect is observed for the largest transactions.

These results disaggregated by purchase size are consistent with individuals engaging in more tax-motivated trading when the tax consequences of the trade are larger. However, they could also be explained by a correlation between investor sophistication and purchase size. To address this alternative explanation, in Table 6 we disaggregate results by both size of the purchase and the total brokerage account balance at the end of the year prior to the stock purchase (our proxy for financial sophistication). The relation between accrued gains and losses and stock realizations is fairly robust across account balances. We also find that in taxable accounts, regardless of the overall size of the account, gains are less apt to be realized and losses are more apt to be realized in December than in other months for large purchases (i.e., $\$ 10,000$ or more) than they are for smaller purchases. As shown in the last two columns, greater tax-motivated trading for larger purchases, where the tax consequence of the transaction is greater, also is robust to the inclusion of investor-specific baselines.

The LOSS and GAIN effects estimated so far are averages across all holding periods, yet we know that these effects may differ by holding period. For example, the GAIN effect might be positive shortly after purchase, as high returns induce traders to sell and lock in gains due to the disposition effect, while over the long-term, an investor may be reluctant to realize a sizeable gain as a result of the associated tax penalty. Previous research on loss realizations also suggests that whether the losses are long-term or short-term also can be important for realization decisions. To explore this issue, we generalize equation (4) to allow both GAIN and LOSS effects to differ by holding period. This yields the specification

$$
\begin{aligned}
& X \beta_{\mathrm{i}, \mathrm{t}}=\beta_{1} * \mathrm{GAIN}_{\mathrm{i}, \mathrm{t}-1}+\beta_{2} * \mathrm{GAIN}_{\mathrm{i}, \mathrm{t}-1} *(\text { Month } \leq 6)_{\mathrm{i}, \mathrm{t}}+\beta_{3} * \mathrm{GAIN}_{\mathrm{i}, \mathrm{t}-1} *\left(\text { Month }_{7-12}\right)_{\mathrm{i}, \mathrm{t}}+ \\
& \beta_{4} * \mathrm{GAIN}_{\mathrm{i}, \mathrm{t}-1} * \text { December }_{\mathrm{i}, \mathrm{t}}+\beta_{5} * \mathrm{GAIN}_{\mathrm{i}, \mathrm{t}-1} *(\text { Month } \leq 6)_{\mathrm{i}, \mathrm{t}} * \text { December }_{\mathrm{i}, \mathrm{t}}+ \\
& \beta_{6} * \mathrm{GAIN}_{\mathrm{i}, \mathrm{t}-1} *(\text { Month 7-12) })_{\mathrm{i}, \mathrm{t}} * \text { December }_{\mathrm{i}, \mathrm{t}}+\beta_{7} * \operatorname{LOSS}_{\mathrm{i}, \mathrm{t}-1}+ \\
& \beta_{8} * \operatorname{LOSS}_{\mathrm{i}, \mathrm{t}-1} *(\text { Month } \leq 6)_{\mathrm{i}, \mathrm{t}}+\beta_{9} * \operatorname{LOSS}_{\mathrm{i}, \mathrm{t}-1} *(\text { Month 7-12) })_{\mathrm{i}, \mathrm{t}}+ \\
& \beta_{10} * \operatorname{LOSS}_{\mathrm{i}, \mathrm{t}-1} * \text { December }_{\mathrm{i}, \mathrm{t}}+\beta_{11} * \operatorname{LOSS}_{\mathrm{i}, \mathrm{t}-1} *(\text { Month } \leq 6)_{\mathrm{i}, \mathrm{t}} * \text { December }_{\mathrm{i}, \mathrm{t}}+ \\
& \beta_{12} * \operatorname{LOSS}_{\mathrm{i}, \mathrm{t}-1} *\left(\text { Month 7-12) }_{\mathrm{i}, \mathrm{t}} * \text { December }_{\mathrm{i}, \mathrm{t}}+\beta_{13} * \text { December }_{\mathrm{i}, \mathrm{t}}+\right.
\end{aligned}
$$

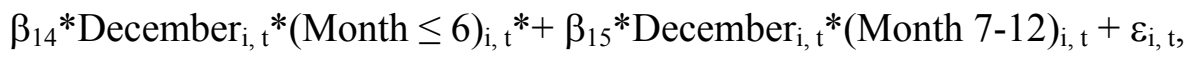


where variables such as "Month 7-12" are indicator variables that describe a holding period of between 7 and 12 months. This specification permits us to study both the timing of sales relative to the turn of the year and the timing relative to the expiration of the $12^{\text {th }}$ month since purchase, the holding period that qualified for short-term tax status during our sample.

Table 7 reports estimates of the model described in equation (6). The coefficient patterns uncover richer trading patterns based on gains and losses than the estimates in Table 4 suggested. For assets with accrued gains, larger gains result in higher sale probabilities in the first six months after acquisition of the asset. This effect is attenuated in the next six months of asset holding and, after twelve months, larger gains exert a negative effect on sale probabilities. Thus, controlling for holding period suggests that the disposition effect is concentrated among short-term holdings, while the capital gains tax lock-in effect prevails at longer holding periods. For example, a capital gain of $25 \%$ is associated with a $22 \%$ increase in the monthly hazard rate of selling stock in a taxable account during the first six months after purchase, but, conditional on having held the stock for one year, a $25 \%$ capital gain is associated with a $6 \%$ reduction in monthly hazards rates. The differential impact of gains on realization behavior over different holding periods suggests that the Odean (1998) disposition result is driven by high-frequency traders with short-term horizons. With respect to losses, the negative coefficient on LOSS*December is stronger if the stock was purchased within the prior six months, so that the loss would be treated as short-term under the income tax, than if the holding period is longer.

The last two columns of Table 7 report separate hazard models for taxable and tax-deferred accounts. The positive effect of GAIN on realization rates at short holding periods is more pronounced in tax-deferred than it is in taxable accounts. The negative effect of accrued gains on realizations after a stock has been held for twelve months is statistically significantly different from zero for taxable accounts, but not for tax-deferred accounts. For example, a capital gain of $25 \%$ is associated with a $22 \%$ increase in the monthly hazard rate of selling stock in a taxable account during the first six months since purchase ( $28 \%$ in tax-deferred accounts), but, conditional on having held the stock for one year, a $25 \%$ capital gain is associated with a $6 \%$ reduction in monthly hazard rates. There is no relation between past gains and subsequent sales after the stock has been held one year in tax-deferred accounts.

The loss-realization effects in December are particularly strong in taxable accounts, although there is a statistically significant and substantively important effect for tax-deferred accounts as well. This realization of losses in the tax-deferred accounts in December cannot be attributed to tax effects and would seem to occur at an inopportune time, given the realization of losses occurring in taxable 
accounts in December along with the historical boost in January returns for these previous loser stocks. A larger loss reduces the probability of sale in both taxable and tax-deferred accounts, but the reduction is larger for tax-deferred accounts, where there is no tax benefit to realizing the loss, at least at short holding periods.

The results in Table 7 assume that the tax incentives for realizing short and long-term gains remain stable throughout our sample period, even though they do not. In 1993, the Omnibus Budget Reconciliation Act increased the top short-term capital gains tax rate from 31 percent to 39.6 percent. The long-term capital gains tax rate was capped at 28 percent throughout our sample period. Thus, the incentive to realize losses short-term and to defer gains until they are long-term was greater after 1993 than it had been before. In unreported results, we allow the coefficients on LOSS*(0-6 month holding period) and LOSS*(7-12 month holding period) to differ before and after the short- term rate increase. The coefficients on these LOSS variables interacted with December are between two and three times larger in the high tax-rate regime than they are in the low tax-rate regime, consistent with the greater incentive to realize short-term capital losses at year-end in the high tax-rate regime. We also find a lower probability of recognizing short-term gains, particularly for positions held for less than six months, in the regime with the higher tax rate on short-term gains. Thus, as predicted, households were less apt to realize short-term gains and more apt to realize short-term losses in December after the increase in short-term capital gains tax rates.

The estimates in Tables 4 through 7 assume that hazard rates of selling are constant across stocks, conditional on their GAIN and LOSS history since purchase. Models of optimal portfolio behavior, however, suggest that realization decisions should depend not only on the accrued capital gain or loss, but also on the volatility of the stock's price. For example, Constantinides (1984) proposes realizing losses of volatile stocks, before the opportunity to capture the associated tax deduction is lost. On the other hand, if the disposition effect is a key determinant of trades, investors' propensity to realize gains (losses) may increase (decrease) with volatility, as the likelihood of a gain turning to a loss and vice versa rises with volatility.

To explore the effect of volatility on gain and loss realizations, Table 8 reports estimates of a generalized version of specifications (4) and (6) that includes interactions of an indicator variable for whether the stock has a gain or loss since purchase with the price volatility of the stock measured over the past 24 months. The resulting coefficients on volatility are statistically significantly different from zero and they suggest that volatility has different effects on realization behavior depending on whether the stock has increased or decreased in value since the time of purchase. A higher volatility stock with a gain is more likely to be sold, consistent with an expanded disposition 
effect in which investors try to sell and thereby lock in gains on more volatile securities. A higher volatility stock with a loss, however, is less likely to be sold than a comparable less-volatile stock with the same loss. One potential explanation for this finding is that investors believe that it is more likely that a highly volatile stock that has declined since the time of purchase will rebound and generate a gain. The volatility effects do not appear to differ between taxable and tax-deferred accounts. These results are not consistent with the tax-timing strategies discussed by Constantinides (1984), perhaps because of the presence of wash sale rules (an issue we explore address in Section III below).

The last three columns of Table 8 show the impact of interacting volatility, indicator variables for gain or loss, and holding period indicators. The strong positive effect of volatility on the realization probability for gains is concentrated at holding periods of less than twelve months. At holding periods of more than one year, the positive effect of volatility on gain realization is greater for stocks held in tax-deferred accounts than it is for stocks held in taxable accounts, mirroring the results we find for returns.

The results in Table 8 suggest that there are differences in realization probabilities across different stocks. Volatility is one characteristic that is correlated with such differences. To allow for more general differences, we estimate hazard models like those in equation (6) with stock-specific baseline hazards. We also estimate this specification with investor-specific baselines, revisiting the results reported in Table 4, but including a more elaborate set of covariates. It is not possible to have both investor-specific and stock-specific hazard rates at the same time, as then the coefficients would only be estimated from the very few households that bought the same stock multiple times. Table 9 reports our findings from these models. The first three columns present results from a model with investor-specific baselines, while the last three report results with stock-specific baselines. Most of the coefficient estimates for GAIN, LOSS, and their interaction terms are similar to those in Table 7, although with investor-specific baselines the impact of GAIN on realization probabilities beyond the twelve-month horizon is only statistically significantly less than zero at the 90 percent confidence level. With investor-specific baselines, we continue to find support for the disposition effect in both taxable and tax-deferred accounts, as well as increased tax-loss selling in December, although the point estimates of LOSS*December lack statistical significance over some holding periods. The results in Table 9 nevertheless suggest that our earlier findings with respect to GAIN and LOSS are not simply an artifact of investor or stock heterogeneity. For example, the relation between past performance and stock sales cannot be explained by buy-and-hold investors investing in large, value stocks that did not perform as well as technology stocks bought by short-horizon investors did. 
Even though the GAIN and LOSS coefficients are relatively stable, standard statistical tests reject the assumption of the same hazard function structure for all investors and for all firms. The Grambsch-Therneau (1994) test for the validity of the proportional hazards model across all variables rejects this model at high confidence levels for tax-deferred accounts $(p$-value $=0.006)$ and marginally for taxable accounts ( $\mathrm{p}$-value $=0.092$ ) when there is a single nonparametric baseline hazard. The only variable that violates the proportionality assumption is the interaction between GAIN and a holding period of less than six months, suggesting that the hazard model has some difficulty handling the strong realization rates associated with very short-term gains. However, with investor-specific nonparametric baseline hazards or with stock-specific baseline hazards, we no longer reject the null hypothesis of the proportional hazards model, suggesting the allowance of these forms of heterogeneity into the model accommodates the high realization rates associated with shortterm gains.

The results in Table 9 suggest that the coefficients on our covariates are not very sensitive to the inclusion of investor- or stock-specific baselines. Yet the results do not convey a sense of the underlying heterogeneity in realization rates that these specifications permit. To provide such a sense, we tabulate several summary statistics for the hazard rates associated with stock sales at holding periods of two through twelve months. Figure 6 shows the dispersion of hazard rates both when we allow for investor-specific baseline hazards and when we allow for stock-specific baselines (i.e., the specifications displayed in Table 9). The findings for the seventh month sale probabilities, for example, illustrate the range of selling probabilities. The interquartile range for the hazard rates when we allow for stock-specific baselines is from a 3.2 percent probability of sale to an 8.3 percent probability. When we allow for investor-specific baselines, the dispersion is even greater; the interquartile range in sale probabilities is from 4.4 percent to 12.8 percent. These results suggest that there are some households with very low trading rates and other households with much higher rates. Nonetheless, after allowing for this dispersion in trading propensities in our model, the effect of past returns is essentially unchanged, suggesting that both heterogeneity and state dependence are important determinants of realization behavior.

Allowing for stock-specific and investor-specific baseline hazards relaxes one of the important restrictions associated with the proportional hazards model. While we cannot allow for both types of baseline heterogeneity simultaneously, we can estimate models that allow for investor heterogeneity as well as a limited amount of stock-specific heterogeneity. We do this by allowing for stock-specific intercept terms in the parametric part of the hazard model, along with investor-specific baselines. Therefore, the model parallel to those in equations (3) and (4) would be: 


$$
h_{i}(t)=\gamma_{i}(t) * e^{X \beta i j, t}
$$

and

$$
\begin{aligned}
\mathrm{X} \beta_{\mathrm{ij}, \mathrm{t}}= & \delta_{\mathrm{j}}+\beta_{1} * \mathrm{GAIN}_{\mathrm{i}, \mathrm{t}-1}+\beta_{2} * \mathrm{GAIN}_{\mathrm{i}, \mathrm{t}-1} * \text { December }_{\mathrm{i}, \mathrm{t}}+\beta_{3} * \operatorname{LOSS}_{\mathrm{i}, \mathrm{t}-1}+ \\
& \beta_{4} * \mathrm{LOSS}_{\mathrm{i}, \mathrm{t}-1} * \text { December }_{\mathrm{i}, \mathrm{t}}+\beta_{5} * \text { December }_{\mathrm{i}, \mathrm{t}}+\varepsilon_{\mathrm{i}, \mathrm{t}},
\end{aligned}
$$

where $\delta_{\mathrm{j}}$ denotes a stock-specific intercept for firm $\mathrm{j}$. This specification allows stock-specific shifts in the level of the baseline hazard rate, but not in its shape.

Because of computational constraints, to estimate the model in (3') and (4') we need to restrict our sample to trades in a subset of stocks. We focus on the one hundred stocks with the largest number of purchases in our sample. While we have 677,422 stock-month observations in our complete data set for taxable accounts, the 100-largest-firm data subset contains 281,290 observations. When we include tax-deferred as well as taxable accounts, the change in sample size is from 1,002,382 observations to 417,594. Table 10 reports estimates from this specification, as well as from the one that replaces (4') with a more extensive set of covariates allowing for holding period interactions.

When we estimate (4') for taxable accounts only, the coefficient on GAIN is small and statistically indistinguishable from zero, with a $25 \%$ gain since purchase leading to a $7 \%$ lower monthly hazard rate of sale in taxable accounts relative to tax-deferred accounts (i.e., $\mathrm{e}^{(-0.30) *(-0.25)}-1$ $=-0.07$ ), comparable to the parsimonious specification with a single nonparametric baseline hazard presented in Table 4. The evidence that losses reduce selling probabilities, except in December, also remains very clear. The estimates in the third column, for example, suggest that in December the proportional difference in hazard rates between a taxable and a tax-deferred account for a stock with a 25 percent loss since purchase is $\mathrm{e}^{(-5.13)^{*}(-0.25)}=3.61$. Thus, a December sale is more than three times more likely in a taxable account as it is in a tax-deferred account. When we disaggregate the GAIN effect by holding period, we still find a substantial positive effect of GAIN at holding periods of between one and six months, as the disposition effect dominates. This effect, as well as a positive GAIN effect at holding periods between seven and twelve months, is much more pronounced in taxdeferred accounts than it is in taxable accounts, consistent with the lock-in effect found earlier.

\section{B. Tax-Loss Selling and the Supply of Losses and Gains}

One dimension along which investors differ, and which directly affects the tax cost of realizing gains and the tax benefit of realizing losses on a particular investment, is the amount of gains or losses realized elsewhere in their portfolio. There is a $\$ 3,000$ limit on the value of net 
capital losses that can be used to offset other income. Losses in excess of this amount must be carried forward to offset future gains or future ordinary income. Poterba (1987) found that relatively few investors faced this limit as a binding constraint in the early 1980s, although more recent work by Auerbach, Burman, and Siegel (2000) suggests that this is currently a binding constraint for a substantial group of taxpayers. For an individual investor, the incentive to realize losses at the end of the year is increasing in gains realized during the year-to-date.

Very few prior studies have been able to test for the impact of such incentives, primarily because of data limitations. For investors in Finland, Grinblatt and Keloharju (2001, 2004) use a unique data set on asset sales and tax liability and find that end-of-year tax-loss selling depends on whether investors have substantial losses or substantial gains from their trading activity earlier in the year. In the U.S., Poterba and Weisbenner (2001), Grinblatt and Moskowitz (2004), and several other studies find evidence suggestive of this behavior using the year-to-date return on the aggregate stock market as a proxy for whether the household will have realized capital gains earlier in the year. They find that the amount of year-end loss realizations, the magnitude of the December decline, and the January increase in the price of stocks with embedded losses depend on whether the aggregate stock market has increased or declined during the year.

The present data set permits a more direct test of how end-of-year loss trading responds to an individual's year-to-date portfolio realizations. We can evaluate the net gain or loss realizations in the investor's taxable account at this brokerage firm in the first eleven months of the year and then assess whether these realized gains or losses predict December realizations. This measure of gains and losses is imperfect because we are only aware of the trades executed at the brokerage firm that provided the data and, moreover, we do not know the purchase price of some of the positions (e.g., those that were purchased prior to the start of the sample in January 1991). Thus, we focus on the December trading activity of households for which we know the basis of stocks sold in the prior eleven months and hence can calculate the total realized capital gain or loss. Because this is an imperfect measure, we also consider a second measure of demand for realized losses: the stock market return in the first eleven months of the year. While not all investors earn the market return, this should provide some indication of other losses or gains that are available. We focus on trading decisions in December within the first 12 months since purchase and estimate a linear probability model for the probability of selling stock in December as a function of GAIN, LOSS, and these two measures of "loss demand."

Table 11 reports our findings for the probability of selling stocks in December, with GAIN, LOSS, and our indicators of loss demand as the key covariates. We consider trading in the month of 
December as well as trading in the last week of that month. The results show that, in taxable accounts, the likelihood of selling a stock that has declined since purchase rises if the market return for the year is negative. For example, a $25 \%$ market return is associated with a two percentage point increase (i.e., $0.20 * 11.4$ ) in the probability of realizing a loss in December, a rather large effect given that baseline hazard rates for December sales are less than ten percentage points. There is a reduction in the chance of selling appreciated shares if the market has risen for the year, consistent with the notion that households will have fewer tax incentives to realize gains if they cannot be shielded with losses elsewhere in the portfolio.

Similarly, we find a pronounced positive interaction effect of an indicator variable for a stock that has declined since its date of purchase and the total amount of capital gains realized during the year. For example, a household with $\$ 5,000$ of realized capital gains through November has a onepercentage point higher likelihood of realizing a loss in December than a household with no realizations entering December does. We do not find an effect from an interaction between an indicator for a stock with a gain since purchase and our measure of the gains realized during the year.

While the left panel of Table 11 focuses on taxable accounts, the right panel focuses on the difference between taxable and tax-deferred accounts. The impact of gain realizations on the probability of selling loss-producing stocks is clearly centered in the taxable rather than the taxdeferred account. In unreported analyses, we replicate the analysis in Table 11 for all the other calendar months. We find that the effect of year-to-date realized capital gains realizations upon sales of stocks with losses (gains) is strongest (weakest) in the month of December. Therefore, the closer the individual investor gets to the end of the year, and thus the clearer picture the investor has of the total capital gains that will be realized in the portfolio, the stronger the effects of realized gains in the portfolio on tax-loss selling. These results suggest that at least some investors seek to minimize their tax liability through end-of-year tax trading and that activity elsewhere in the portfolio affects their trading decisions.

\section{Parametric Baseline Hazard Models}

Our data set includes only six years of transactions data and thus does not report the purchase date for securities that were held by investors at the beginning of the sample period. Therefore, the nonparametric baseline approach employed above cannot be used to estimate the probability of holding a stock for periods of more than six years. One way to use these data to suggest patterns of longer-horizon trading behavior is to impose a functional structure on the hazard function at short holding periods, and then to invoke this functional form to make projections at longer holding 
periods. A simple parametric restriction of baseline hazard function, which yields the Gompertz proportional hazards function, constrains this baseline hazard to follow an exponential path:

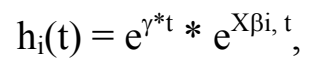

where the parameter $\gamma$ determines the rate of decay, or growth, of the monthly baseline hazard rates.

To explore the fit of this functional form, we plot estimates for our entire data sample of the nonparametric baseline hazard, fitted values from the Gompertz baseline hazard, and two alternative parametric specifications, the Weibull and the log-normal. Figure 7a considers the hazard rates of stock sales beginning in the second month after purchase, and Figure $7 \mathrm{~b}$ considers sales conditional on the stock having been held for six months. The log-normal and the Weibull decay too slowly to track the nonparametric baseline hazard, while the Gompertz functional form tracks the nonparametric baseline quite closely. Both Wilcoxon and Kolmogorov-Smirnov tests reject the goodness-of-fit of the Weibull and log-normal distributions at very high levels of confidence. The Wilcoxon test does not reject the Gompertz model ( $\mathrm{p}$-value $=0.19$ ), although the KolmogorovSmirnov test does, primarily because of the shape of the Gompertz function for short holding periods. If we focus on the fit of the Gompertz models at holding periods beyond six months, we do not reject the null hypothesis that the Gompertz describes the observed pattern of hazard rates.

In light of these findings, we use the Gompertz model as an alternative to the proportional hazards model with a nonparametric baseline. Table 12 presents proportional hazards estimates that are similar to those in Table 7, but in which the Gompertz baseline hazard replaces the nonparametric baseline hazard. Most of the key findings are very similar across the two tables. GAIN continues to have a depressing effect on stock sales after a stock has been held for a given period, LOSS has a positive coefficient, so again a loss reduces the likelihood of selling stock and the LOSS*December coefficient suggests an important tax-loss selling effect at year-end. The estimates of the Gompertz decay parameter, $\gamma$, suggest modest decay in the sale probability with the holding period, with the decay rate greater for taxable than for tax-deferred accounts.

The Gompertz parameters reported in Table 12 can be used to compute the expected holding period for common stock purchases. Such computations are a natural input to the calculations of the expected burden of the capital gains tax and provide information about the economic importance of past performance in affecting stock sales. Table 13 presents summary information on the sale probabilities and the expected holding periods conditional on a stock having been held for a given holding period, without conditioning on past performance. The first two columns report summary values of the probability of selling a stock within a given time period after purchase. The second two 
columns indicate the probability that the stock will be sold within five years since the date of purchase, conditional on it having been held for various lengths of time.

The third pair of columns computes the probability that the stock will ever be sold. This affects the prospective burden of the capital gains tax because stock that is held until the death of the owner qualifies for a "basis step up," which effectively eliminates capital gains tax liability on the gains during the life of the owner. The estimates of the probability that the stock is never sold are obtained via the Gompertz model. Because of the exponential baseline, the cumulative probability of sale asymptotes to some constant that is less than or equal to one. One minus this constant reflects the probability the stock is never sold. Finally, the last two columns compute the expected holding period of the stock. When calculating the expected holding period of the stock, the probability of no sale is multiplied by 20 years and then added to the product of the expected holding period, conditional on a sale being made (in a probabilistic sense), and the probability of sale as computed from the Gompertz model. Thus, the expected holding periods are computed under the somewhat conservative assumption that the maximum holding period is 20 years. We view the choice of 20 years as indeed conservative; capital gains taxation upon realization and basis step-up at death could lead toward much larger holding periods. Moreover, hazard rates of selling stocks decline fairly sharply, approaching zero after only a few years since purchase.

The results suggest that, once stock has been held for a year, future turnover probabilities are modest. According to the Gompertz model, there is a 65 percent chance that a stock held in a taxable account will never be sold if it has been held for one year. The non-parametric estimate of the probability that the stock will be sold within five years since purchase conditional on being held one year is 32 percent. Given that hazard rates asymptote to almost zero after a few years, this suggests that, if a stock is not sold within five years, the chance that it will ever be sold is very small. Thus, the fact that the "probability stock is sold within five years" column plus the "probability of no sale" column approximately adds up to $100 \%$ provides indirect evidence of the appropriateness of the exponential baseline assumption that underlies the Gompertz model. After two years of ownership, the probability that the stock will be sold within five years of purchase drops to 18 percent, and the chance that the stock will never be sold rises to 77 percent. For a tax-deferred account, the probability of selling before five years from the time of purchase is higher ( 29 percent), and the probability of never selling is substantially lower (61 percent). The rightmost columns show that the expected stock holding period for a stock in a taxable account at the time of purchase is just over six years months. This expected holding period rises to just under 14 years after a stock has been held for a year. The expected holding period for stocks in taxable accounts exceeds that in tax-deferred 
accounts, with the expected difference in holding periods growing from nine months at the purchase date to 29 months conditional on the stock having been held a year.

The calculations in Table 13 do not distinguish between stocks with gains and losses since the time of purchase, yet the earlier hazard models suggest that the price trajectory has an important effect on turnover probabilities, with a capital gains lock-in effect emerging. To illustrate the magnitude of the lock-in effect, we repeated the calculations in Table 13 assuming that a stock maintains a $50 \%$ gain. The probability that a stock with a gain of $50 \%$ is never sold is estimated to be $61 \%$ if that stock is held in a taxable account, compared with $41 \%$ if it is held in a tax-deferred account. The 20 percentage point differential is comparable to the 16 percentage point lower probability that a stock with an accrued capital gain will be sold within five years in a taxable account relative to a tax-deferred account. The differential in hazard rates accumulates over time and leads to an estimated 29-month greater expected holding period for a stock with a $50 \%$ gain in a taxable account relative to a tax-deferred account. If we condition on the stock having been held at least one year, the difference rises from 29 to 39 months.

\section{Evidence on Wash Sales and Restarting Tax Options}

In some cases, particularly when realized losses are involved, the sale of a given stock position may not represent the end of an investor's connection with this security. If the stock sale is followed by another purchase of the same stock, then the sale may have been motivated by tax considerations and the investor may have sold even though his or her long-term objective was to hold the underlying security. "Wash sale" restrictions preclude an investor from claiming the capital loss associated with a stock sale if the stock is repurchased within thirty days of the loss-generating sale.

There has been very little research on whether investors repurchase securities they have previously sold to realize tax losses. One notable exception is Grinblatt and Keloharju's (2004) analysis of Finnish data, which suggests that a substantial number of investors repurchase stocks that they sell to generate tax losses. However, Finland does not have wash sale restrictions, so an individual can repurchase a share immediately after selling for a tax loss, and the trade will not disallow the tax benefit associated with the loss realization. In the United States, the 30-day loss sale requirement makes it more difficult to generate a tax loss without some change in portfolio characteristics. The extent of portfolio dislocation is unclear, however, because an investor could purchase a security that is highly correlated with the one that has just been sold and hold this security until the original security is repurchased. 
Table 14 shows the probability that an investor repurchases a security within 30 days since the date of sale. The table considers stocks purchased in both taxable and tax-deferred accounts. It also distinguishes sales on which the investor realized a gain from those on which there was a loss. Wash sale restrictions only apply to losses in taxable accounts. We first examine the propensity to repurchase stocks in a taxable account following sales in December and in all other months. We distinguish December on the grounds that tax-motivated sales are most likely to occur in that month. The first column of Table 14 focuses on sales with realized losses. For sales in taxable accounts in December, there is a 4.5 percent chance that the investor will repurchase the security in the taxable account during the thirty days after sale, thereby voiding the tax benefits associated with loss realization. The analogous probability for sales that occur in months other than December is 8.5 percent, with the differential probability of -4.0 percent being highly significant. These results suggest that investors are less likely to repurchase stocks with losses when they sell them in December than in other months, which we interpret as evidence that investors are more tax-conscious in their December sales. These results are also in direct contrast to Grinblatt and Keloharju (2004), who find that the investors who realize losses in December in Finland, where there are no wash sale rules, are more apt to immediately repurchase the stock than are the investors realizing losses in other calendar months.

The second column of Table 14 presents information on the probability of repurchasing the stock after realizing a gain. The probability of repurchasing the stock after a gain realization is greater than the respective probability of repurchasing following tax-loss sales. For December sales in taxable accounts, there is a 10.4 percent chance that the gain-producing stock is repurchased in a taxable account within a month. The third column summarizes the difference between the probabilities of repurchasing a stock when the sale generated a loss and when it generated a gain. For sales in taxable accounts, the difference in the probability of repurchasing a share in a taxable account within 30 days when that share has been sold for a loss and when the share has been sold for a gain is -5.9 percent when the sale occurs in December, the comparable difference being -3.6 for sales in non-December months, with the difference in differences a statistically significant -2.3 .

The right panel of Table 14 presents estimates of the probability a stock that has been sold is repurchased in the second month following the sale. Unlike the repurchase activity in the first month after the sale, which is subject to wash sale rules and is significantly lower for losses realized in December relative to other months, there is no differential in repurchase rates during the second month after purchase. However, if the wash sale rules resulted in pent-up demand to repurchase the 
stock sold at a loss in December, one might expect a boost in the repurchase rate in the second month following these tax-motivated sales. We find no evidence of such an effect.

Our results suggest that wash sale rules reduce the probability that a stock is immediately repurchased following a tax-loss sale in December. Because, by definition, investors in our sample have both taxable and tax-deferred accounts, it is possible for a stock purchase in a tax-deferred account to follow a sale in a taxable account. Hermann (2003) notes that the IRS has issued conflicting guidance regarding the extent to which these transactions may affect the use of tax losses to offset other income. Table 15 reports the probability of purchasing the same stock in a taxdeferred account following a sale in a taxable account. It also considers the probability of repurchasing in a tax-deferred account following a sale in that account. Since there are no wash sale rules to restrict sales followed by purchases in these accounts, the rate of repurchase in the taxdeferred accounts may provide a baseline against which to judge the behavior in taxable accounts. The results suggest that, even though wash sale rules potentially could have been skirted with offsetting transactions in taxable and tax-deferred accounts, such trades were relatively rare.

The low frequency of wash sales is a challenge to the predictions of optimizing models of capital gain realizations such as Constantinides (1984), Dammon, Dunn, and Spatt (1989), and Dammon and Spatt (1996). In these models, provided transaction costs are low enough and especially when there is a differential between the tax rate on short-term and long-term gains, investors have incentives to sell shares and realize losses and then to purchase shares again so that over a longer horizon their portfolio is not affected by their tax-trading activity. However, we find that few investors are realizing losses and subsequently repurchasing securities.

\section{Conclusion}

This paper offers novel evidence on the stock-trading pattern of individual investors. In past work, it has been difficult to assess the importance of tax-related and psychological motivations to trade because the two have offsetting implications for the effect of past returns on stock realizations. Comparing investors' realizations in their taxable and tax-deferred accounts provides a means to identify the magnitude of tax-motivated trading. Using data from a large discount brokerage house, we find evidence of a lock-in effect for capital gains, i.e., a desire to postpone stock sales and their associated tax liability, in taxable accounts. This effect is more pronounced for larger stock purchases and it intensifies the longer the stock has been held. We also present evidence of a higher propensity to realize losses in taxable accounts relative to tax-deferred accounts throughout the calendar year, with tax-loss selling being most pronounced in December. Year-end tax-loss selling 
is stronger among households that have realized net capital gains during the year, and if the holding period of the stock would allow the loss to qualify for short-term tax treatment.

An appealing feature of the brokerage house data is that we observe individuals trading several times, and we find substantial heterogeneity in individuals' propensity to sell stock. However, the results obtained are robust to controls for investor heterogeneity in trading behavior and stock-specific characteristics, suggesting both investor heterogeneity and past performance are important in explaining stock sales. Finally, losses realized in taxable accounts in December appear to be affected by wash sale restrictions. The chance that a stock will be repurchased within 30 days, if sold at a loss in December, is substantially lower than the chance of such a repurchase following sales in other months.

Our findings on the path-dependence of stock sale probabilities and the substantial differences between realization rates for appreciated and depreciated stocks suggest that modeling the burden of the capital gains tax must move beyond simple models with a constant probability of asset sale, such as those developed by Bailey (1969) and Protopapadakis (1983). Our results further suggest that some investors are sensitive to tax incentives, while others are tax-oblivious. Barber and Odean (2004) note that investors trade with higher frequency in their taxable than they do in their tax-deferred accounts. On its face, this finding appears inconsistent with tax minimization, yet our results suggest that there are important differences between trading in taxable and tax-deferred accounts and that these differences are consistent with tax incentives affecting trading in taxable accounts.

Given the evident heterogeneity in trading patterns, there is a clear need for a framework that can be used to categorize investors as tax-efficient or tax-insensitive. One way to do this is by studying the number of investors who fail to execute tax-reducing trades. In our data set, 21 percent of all stock purchases of $\$ 10,000$ or more resulted in a realized loss within one year, and 38 percent resulted in a realized gain within a year. Of the remaining 40 percent of stock purchases, 18 percent (45 percent of this category) had losses at the end of twelve months that could have been realized, but were not. This suggests that nearly one-half of the investors who could have realized a short-term loss did not avail themselves of the opportunity. We cannot conclude that investors who did not realize short-term losses were foregoing substantial tax benefits because they might have been unable to use the tax losses to reduce their tax liability, but we suspect that many of these investors could have reduced their tax liability by realizing the losses. Measuring the cost to investors of such taxinefficient behavior is a clear avenue for future research. 


\section{References}

Auerbach, Alan, Leonard Burman, and Jonathan Seigel, 2000, "Capital Gains Taxation and Tax Avoidance: New Evidence from Panel Data," in J. Slemrod, ed., Does Atlas Shrug? The Economic Consequences of Taxing the Rich (New York: Russell Sage), 355-388.

Auten, Gerald, and Janette Wislon, 1999, "Sales of Capital Assets Reported on Individual Tax Returns, 1985," Statistics of Income SOI Bulletin, 18 (Spring), 113-136.

Bailey, Martin J., 1969, “Capital Gains and Income Taxation,” in A. Harberger and M. Bailey, eds., The Taxation of Income from Capital (Washington: Brookings Institution), 11-49.

Barber, Brad, and Terrance Odean, 2000, "Trading is Hazardous to Your Wealth: The Common Stock Investment Performance of Individual Investors," Journal of Finance 55, 773-806.

Barber, Brad, and Terrance Odean, 2001, "Boys Will be Boys: Gender, Overconfidence, and Common Stock Investment,” Quarterly Journal of Economics 116, 261-292.

Barber, Brad, and Terrance Odean, 2004, “Are Individual Investors Tax Savvy? Evidence from Retail and Discount Brokerage Accounts,” Journal of Public Economics 88, 419-442..

Constantinides, George, 1984, “Optimal Stock Trading with Personal Taxes,” Journal of Financial Economics 13, 65-89.

Dammon, Robert, Kenneth Dunn, and Chester Spatt, 1989, “A Reexamination of the Value of Tax Options," Review of Financial Studies 2, 341-372.

Dammon, Robert, and Chester Spatt, 1996, "The Optimal Trading and Pricing of Securities with Asymmetric Capital Gains Taxes and Transaction Costs," Review of Financial Studies 9, 921-952.

Feldstein, Martin, Joel Slemrod, and Shlomo Yitzhaki, 1980, "The Effects of Taxation on the Selling and Switching of Common Stock," Quarterly Journal of Economics 94, 777-791.

Gonul, Fusun and Kannan Srinivasan, 1993, “Consumer Purchase Behavior in a Frequently Bought Product Category: Estimation Issues and Managerial Insights from a Hazard Function Model with Heterogeneity," Journal of the American Statistical Association 88 (December), 12191227.

Grambsch, P. M., and T. M. Therneau, 1994, "Proportional Hazards Test and Diagnostics Based on Weighted Residuals," Biometrika 81, 515-526.

Grinblatt, Mark, and Matti Keloharju, 2001, “What Makes Investors Trade?,” Journal of Finance 56, 589-616. 
Grinblatt, Mark and Matti Keloharju, 2004, “Tax-Loss Trading and Wash Sales,” Journal of Financial Economics (forthcoming).

Grinblatt, Mark and Tobias Moskowitz, 2004, "Predicting Stock Price Movements from Past Returns: The Role of Consistency and Tax Loss Selling," Journal of Financial Economics (forthcoming).

Han, Aaron and Jerry Hausman, 1990. "Flexible Parametric Estimation of Duration and Competing Risk Models," Journal of Applied Econometrics, 5:1-28.

Herman, Tom, 2003. "IRS Sows Confusion on a Tax Issue," The Wall Street Journal, May 1.

Kahnemann, Daniel and Amos Tversky, 1979, "Prospect Theory: An Analysis of Decision Under Risk," Econometrica 46, 171-185.

Meyer, Bruce. 1990. “Unemployment Insurance and Unemployment Spells.” Econometrica, 58(4): 757-782.

Odean, Terrance, 1998, “Are investors reluctant to realize their losses?," Journal of Finance 53, 1775-1798.

Poterba, James, 1987, “How Burdensome are Capital Gains Taxes?,” Journal of Public Economics 33, 157-172.

Poterba, James, 2002, “Taxation, Risk-Taking, and Portfolio Behavior," in Alan Auerbach and Martin Feldstein, eds.: Handbook of Public Economics: Volume 3 (North Holland, Amsterdam).

Poterba, James and Scott J. Weisbenner, 2001, “Capital Gains Tax Rules, Tax Loss Trading, and Turn-of-the-Year Returns," Journal of Finance 56, 353-368.

Protopapadakis, Aris, 1983, “Some Indirect Evidence on Effective Capital Gains Tax Rates,” Journal of Business 56, 127-138.

Ritter, Jay, 1988, “The Buying and Selling Behavior of Individual Investors at the Turn of the Year," Journal of Finance 43, 701-717.

Shefrin, Hersh and Meir Statman, 1985, "The Disposition to Sell Winners Too Early and Ride Losers Too Long: Theory and Evidence,” Journal of Finance 40, 777-782.

Strobl, Gunter, 2003, "Information Asymmetry, Price Momentum, and the Disposition Effect," mimeo, Wharton School, University of Pennsylvania.

Wilson, Janette, 2002, "Sales of Capital Assets Reported on Individual Tax Returns, 1998 and 1997," Statistics of Income SOI Bulletin, 22 (Summer), 149-189.

Wilson, Janette, 2003, “Sales of Capital Assets Reported on Individual Tax Returns, 1999," of Income SOI Bulletin, 23 (Summer), 132-154. 
TABLE 1 - Summary StATistics On COMMON StOcK PuRCHASES

\begin{tabular}{|c|c|c|c|c|c|c|c|c|c|c|c|c|}
\hline & \multicolumn{4}{|c|}{ All Accounts } & \multicolumn{4}{|c|}{ Taxable Accounts } & \multicolumn{4}{|c|}{ Tax-deferred Accounts } \\
\hline & $\begin{array}{c}\# \\
\text { Purchases } \\
\end{array}$ & $\begin{array}{l}\text { Mean } \\
\text { \$ Amt. }\end{array}$ & $\begin{array}{l}\geq \$ 10 K \\
\text { (in \%) }\end{array}$ & $\begin{array}{c}\text { Sold } \\
\text { (in \%) }\end{array}$ & $\begin{array}{c}\# \\
\text { Purchases } \\
\end{array}$ & $\begin{array}{l}\text { Mean } \\
\$ \text { Amt. }\end{array}$ & $\begin{array}{l}\geq \$ 10 K \\
\text { (in \%) }\end{array}$ & $\begin{array}{c}\text { Sold } \\
\text { (in \%) }\end{array}$ & $\begin{array}{c}\# \\
\text { Purchases } \\
\end{array}$ & $\begin{array}{l}\text { Mean } \\
\text { \$ Amt. }\end{array}$ & $\begin{array}{l}\geq \$ 10 K \\
\text { (in \%) }\end{array}$ & $\begin{array}{c}\text { Sold } \\
\text { (in \%) }\end{array}$ \\
\hline 1991 & 61,808 & $\begin{array}{c}7,902 \\
(4,137)\end{array}$ & $\begin{array}{c}19 \\
{[61]}\end{array}$ & $\begin{array}{c}69 \\
{[75]}\end{array}$ & 39,337 & $\begin{array}{c}8,712 \\
(4,424)\end{array}$ & $\begin{array}{c}22 \\
{[65]}\end{array}$ & $\begin{array}{c}70 \\
{[75]}\end{array}$ & 22,471 & $\begin{array}{c}6,485 \\
(3,750)\end{array}$ & $\begin{array}{c}15 \\
{[52]}\end{array}$ & $\begin{array}{c}67 \\
{[75]}\end{array}$ \\
\hline 1992 & 61,448 & $\begin{array}{c}8,281 \\
(4,375)\end{array}$ & $\begin{array}{c}20 \\
{[63]}\end{array}$ & $\begin{array}{c}66 \\
{[74]}\end{array}$ & 36,830 & $\begin{array}{c}9,279 \\
(4,748)\end{array}$ & $\begin{array}{c}23 \\
{[67]}\end{array}$ & $\begin{array}{c}67 \\
{[74]}\end{array}$ & 24,618 & $\begin{array}{c}6,788 \\
(3,866)\end{array}$ & $\begin{array}{c}16 \\
{[54]}\end{array}$ & $\begin{array}{c}65 \\
{[75]}\end{array}$ \\
\hline 1993 & 66,117 & $\begin{array}{c}8,694 \\
(4,550)\end{array}$ & $\begin{array}{c}22 \\
{[64]}\end{array}$ & $\begin{array}{c}62 \\
{[70]}\end{array}$ & 38,522 & $\begin{array}{c}9,865 \\
(4,995)\end{array}$ & $\begin{array}{c}25 \\
{[69]}\end{array}$ & $\begin{array}{c}62 \\
{[69]}\end{array}$ & 27,595 & $\begin{array}{c}7,059 \\
(3,974)\end{array}$ & $\begin{array}{c}17 \\
{[55]}\end{array}$ & $\begin{array}{c}60 \\
{[71]}\end{array}$ \\
\hline 1994 & 58,814 & $\begin{array}{c}8,967 \\
(4,620)\end{array}$ & $\begin{array}{c}23 \\
{[66]}\end{array}$ & $\begin{array}{c}53 \\
{[64]}\end{array}$ & 33,664 & $\begin{array}{c}9.920 \\
(5,000)\end{array}$ & $\begin{array}{c}25 \\
{[69]}\end{array}$ & $\begin{array}{c}53 \\
{[62]}\end{array}$ & 25,150 & $\begin{array}{c}7,691 \\
(4,125)\end{array}$ & $\begin{array}{c}19 \\
{[60]}\end{array}$ & $\begin{array}{c}53 \\
{[65]}\end{array}$ \\
\hline 1995 & 74,581 & $\begin{array}{l}10,272 \\
(5,185)\end{array}$ & $\begin{array}{c}26 \\
{[70]}\end{array}$ & $\begin{array}{c}49 \\
{[60]}\end{array}$ & 41.500 & $\begin{array}{l}11,635 \\
(5,700)\end{array}$ & $\begin{array}{c}30 \\
{[74]}\end{array}$ & $\begin{array}{c}49 \\
{[59]}\end{array}$ & 33,081 & $\begin{array}{c}8,562 \\
(4,740)\end{array}$ & $\begin{array}{c}22 \\
{[63]}\end{array}$ & $\begin{array}{c}48 \\
{[61]}\end{array}$ \\
\hline 1996 & 91,279 & $\begin{array}{l}10,923 \\
(5,350)\end{array}$ & $\begin{array}{c}28 \\
{[72]}\end{array}$ & $\begin{array}{c}28 \\
{[38]}\end{array}$ & 51,193 & $\begin{array}{l}12,240 \\
(5,712)\end{array}$ & $\begin{array}{c}31 \\
{[76]}\end{array}$ & $\begin{array}{c}28 \\
{[38]}\end{array}$ & 40,086 & $\begin{array}{c}9,241 \\
(4,974)\end{array}$ & $\begin{array}{c}24 \\
{[66]}\end{array}$ & $\begin{array}{c}27 \\
{[37]}\end{array}$ \\
\hline Total & 414,047 & $\begin{array}{r}9,329 \\
(4,762) \\
\end{array}$ & $\begin{array}{c}23 \\
{[67]}\end{array}$ & $\begin{array}{c}52 \\
{[60]}\end{array}$ & 241,046 & $\begin{array}{l}10,404 \\
(5,063)\end{array}$ & $\begin{array}{c}26 \\
{[71]}\end{array}$ & $\begin{array}{c}53 \\
{[60]}\end{array}$ & 173,001 & $\begin{array}{c}7,831 \\
(4,310) \\
\end{array}$ & $\begin{array}{c}20 \\
{[60]}\end{array}$ & $\begin{array}{c}51 \\
{[60]}\end{array}$ \\
\hline
\end{tabular}

Notes: Sample consists of 23,877 households that had both taxable and tax-deferred accounts and that purchased at least one stock between 1/91 and 11/96. The values in parentheses are median dollar amounts. Values in brackets are averages that weigh different purchases by the size of the purchase. 
TABle 2-Distribution of Corporate StOck SALES

\begin{tabular}{|c|c|c|c|c|c|c|}
\hline \multirow[b]{2}{*}{$\begin{array}{l}\text { Length of time } \\
\text { held (months) }\end{array}$} & \multicolumn{4}{|c|}{$\begin{array}{c}\text { Aggregate Stock Sales Reported on } \\
\text { Tax Returns (in percent) }\end{array}$} & \multicolumn{2}{|c|}{$\begin{array}{l}\text { Stock Sales in Taxable Accounts during } \\
1995 \text { in Brokerage Data (in percent) }\end{array}$} \\
\hline & 1985 & 1997 & 1998 & 1999 & Full Sample & $\begin{array}{l}\text { Sales of } \$ 10,000+ \\
\text { Purchases }\end{array}$ \\
\hline 1 & 14.0 & 21.3 & 27.2 & 34.6 & 21.3 & 37.7 \\
\hline $2-3$ & 11.8 & 18.6 & 14.6 & 15.4 & 19.3 & 22.9 \\
\hline $4-6$ & 11.8 & 14.0 & 13.8 & 12.7 & 15.1 & 13.7 \\
\hline $7-12$ & 15.8 & 17.5 & 17.3 & 14.6 & 14.6 & 10.0 \\
\hline $13-18$ & 13.7 & 10.0 & 10.3 & 8.9 & 9.7 & 6.0 \\
\hline $19-24$ & 12.3 & 6.8 & 6.1 & 5.0 & 6.8 & 3.7 \\
\hline $25-36$ & 14.4 & 7.4 & 7.3 & 5.8 & 8.4 & 4.1 \\
\hline $37-48$ & 6.3 & 4.4 & 3.4 & 3.0 & 4.9 & 1.9 \\
\hline
\end{tabular}

Panel B: Distribution by Holding Period and Calendar Month, Breakdown by Realized Gain or Loss

\begin{tabular}{|c|c|c|c|c|}
\hline \multirow[b]{3}{*}{$\begin{array}{l}\text { Length of time } \\
\text { held (months) }\end{array}$} & \multicolumn{2}{|c|}{$\begin{array}{l}\text { Aggregate Stock Sales Reported on } \\
\text { Tax Returns in } 1997 \text { (in percent) }\end{array}$} & \multicolumn{2}{|c|}{$\begin{array}{l}\text { Stock Sales in Taxable Account during } \\
1995 \text { in Brokerage Data (in percent) }\end{array}$} \\
\hline & \multicolumn{4}{|c|}{ Percent of Stock Sales by Holding Period } \\
\hline & Sold w/Gain & Sold w/Loss & Sold w/Gain & Sold w/Loss \\
\hline 1 & 20.4 & 22.9 & 21.2 & 21.3 \\
\hline $2-3$ & 17.4 & 20.6 & 19.7 & 18.5 \\
\hline $4-6$ & 13.1 & 15.7 & 15.8 & 13.7 \\
\hline $7-12$ & 17.4 & 17.8 & 15.7 & 12.6 \\
\hline $13-18$ & 10.8 & 8.6 & 9.4 & 10.1 \\
\hline $19-24$ & 7.4 & 5.9 & 6.2 & 8.0 \\
\hline $25-36$ & 8.7 & 5.3 & 7.6 & 9.8 \\
\hline \multirow[t]{2}{*}{$37-48$} & 4.9 & 3.3 & 4.4 & 5.9 \\
\hline & \multicolumn{4}{|c|}{ Percent of Stock Sales in December } \\
\hline $\begin{array}{l}\text { Short-term } \\
\text { holding period }\end{array}$ & 7.7 & 12.7 & 6.6 & 16.2 \\
\hline $\begin{array}{l}\text { Long-term } \\
\text { holding period }\end{array}$ & 9.5 & 17.9 & 6.4 & 18.2 \\
\hline $\begin{array}{l}\text { All holding } \\
\text { periods }\end{array}$ & 8.4 & 14.2 & 6.6 & 16.9 \\
\hline
\end{tabular}

Notes: The aggregate sales of corporate stock reported on tax returns are provided by Auten and Wilson (1999), Wilson (2002), and Wilson (2003) and authors' calculations. The table focuses on stocks held at most four years. Annual S\&P 500 returns are as follows: $1985=32 \%, 1995=$ $38 \%, 1997=33 \%, 1998=29 \%$, and $1999=21 \%$. The short-term holding period is 12 months or less and the long-term holding period is more than twelve months. 
Table 3-Regression of Monthly Hazard Rate of Selling Stock upon Cumulative Return On Stock ENTERING THE Month, Purchases $\geq \$ 10,000$ (Figures 5A AND 5B)

\begin{tabular}{|c|c|c|c|c|c|c|}
\hline \multirow[b]{2}{*}{$\begin{array}{l}\text { Months since } \\
\text { Purchase }\end{array}$} & \multicolumn{3}{|c|}{$\begin{array}{l}\text { Probability of selling stock in } \\
\text { taxable account }\end{array}$} & \multicolumn{3}{|c|}{$\begin{array}{l}\text { Probability of selling stock in } \\
\text { taxable account relative to selling } \\
\text { stock in tax-deferred account }\end{array}$} \\
\hline & $\begin{array}{l}\text { Constant: } \\
\text { baseline }\end{array}$ & GAIN & LOSS & $\begin{array}{l}\text { Constant: } \\
\text { baseline }\end{array}$ & GAIN & LOSS \\
\hline 1 month & $\begin{array}{l}23.4^{* * * *} \\
(0.8)\end{array}$ & & & $\begin{array}{c}2.7^{* *} \\
(1.4)\end{array}$ & & \\
\hline 2 months & $\begin{array}{l}11.4^{* * *} \\
(0.4)\end{array}$ & $\begin{array}{l}21.7^{* * *} \\
(2.6)\end{array}$ & $\begin{array}{l}9.7^{* * *} \\
(2.2)\end{array}$ & $\begin{array}{c}1.0^{*} \\
(0.6)\end{array}$ & $\begin{array}{l}-19.4^{* * *} \\
(4.6)\end{array}$ & $\begin{array}{r}0.7 \\
(3.6)\end{array}$ \\
\hline 3 months & $\begin{array}{l}8.7^{* * *} \\
(0.3)\end{array}$ & $\begin{array}{l}11.6^{* * *} \\
(1.8)\end{array}$ & $\begin{array}{l}8.2^{* * *} \\
(1.5)\end{array}$ & $\begin{array}{r}0.1 \\
(0.5)\end{array}$ & $\begin{array}{l}-8.9^{* * *} \\
(3.2)\end{array}$ & $\begin{array}{l}-2.5 \\
(2.5)\end{array}$ \\
\hline 4 months & $\begin{array}{l}6.7^{* * *} \\
(0.3)\end{array}$ & $\begin{array}{l}5.8^{* * *} \\
(1.3)\end{array}$ & $\begin{array}{l}6.4^{* * *} \\
(1.2)\end{array}$ & $\begin{array}{r}-0.5 \\
(0.4)\end{array}$ & $\begin{array}{l}-6.2^{* * *} \\
(2.4)\end{array}$ & $\begin{array}{l}-1.6 \\
(2.0)\end{array}$ \\
\hline 5 months & $\begin{array}{l}5.5^{* * *} \\
(0.2)\end{array}$ & $\begin{array}{l}4.7^{* * *} \\
(1.1)\end{array}$ & $\begin{array}{l}5.0^{* * *} \\
(1.0)\end{array}$ & $\begin{array}{l}-0.7^{*} \\
(0.4)\end{array}$ & $\begin{array}{l}-5.4^{* * *} \\
(2.2)\end{array}$ & $\begin{array}{l}-2.5 \\
(1.7)\end{array}$ \\
\hline 6 months & $\begin{array}{l}5.4^{* * *} \\
(0.2)\end{array}$ & $\begin{array}{r}0.7 \\
(0.8)\end{array}$ & $\begin{array}{l}4.6^{* * * *} \\
(0.9)\end{array}$ & $\begin{array}{r}-0.5 \\
(0.4)\end{array}$ & $\begin{array}{l}-6.6^{* * *} \\
(1.8)\end{array}$ & $\begin{array}{l}-0.6 \\
(1.7)\end{array}$ \\
\hline 7 months & $\begin{array}{l}4.6^{* * *} \\
(0.2)\end{array}$ & $\begin{array}{l}1.3^{*} \\
(0.8)\end{array}$ & $\begin{array}{l}2.7^{* * *} \\
(0.9)\end{array}$ & $\begin{array}{r}-0.4 \\
(0.4)\end{array}$ & $\begin{array}{l}-4.5^{* * *} \\
(1.6)\end{array}$ & $\begin{array}{l}-2.8^{* *} \\
(1.4)\end{array}$ \\
\hline 8 months & $\begin{array}{l}3.7^{* * *} \\
(0.2)\end{array}$ & $\begin{array}{r}0.8 \\
(0.5)\end{array}$ & $(0.8)$ & $\begin{array}{l}-0.6^{*} \\
(0.4)\end{array}$ & $\begin{array}{l}-5.5^{* * *} \\
(1.5)\end{array}$ & $\begin{array}{l}-3.2^{* *} \\
(1.4)\end{array}$ \\
\hline 9 months & $\begin{array}{l}3.4^{* * *} \\
(0.2)\end{array}$ & $\begin{array}{l}-0.2 \\
(0.3)\end{array}$ & $\begin{array}{r}0.4 \\
(0.8)\end{array}$ & $\begin{array}{l}-0.7^{* *} \\
(0.4)\end{array}$ & $\begin{array}{l}-3.5^{* * *} \\
(1.2)\end{array}$ & $\begin{array}{l}-3.8^{* * *} \\
(1.4)\end{array}$ \\
\hline 10 months & $\begin{array}{l}3.1^{* * * *} \\
(0.2)\end{array}$ & $\begin{array}{r}0.2 \\
(0.4)\end{array}$ & $\begin{array}{r}1.1 \\
(0.7)\end{array}$ & $\begin{array}{l}-0.8^{* *} \\
(0.4)\end{array}$ & $\begin{array}{c}-1.9 \\
(1.3)\end{array}$ & $\begin{array}{r}-2.1 \\
(1.3)\end{array}$ \\
\hline 11 months & $\begin{array}{l}2.9^{* * *} \\
(0.2)\end{array}$ & $\begin{array}{l}-0.4 \\
(0.3)\end{array}$ & $\begin{array}{r}0.9 \\
(0.7)\end{array}$ & $\begin{array}{l}-0.6^{* *} \\
(0.3)\end{array}$ & $\begin{array}{l}-1.9^{* *} \\
(0.8)\end{array}$ & $\begin{array}{l}-2.4^{* *} \\
(1.1)\end{array}$ \\
\hline 12 months & $\begin{array}{l}2.9^{* * *} \\
(0.2)\end{array}$ & $\begin{array}{l}-0.1 \\
(0.3)\end{array}$ & $\begin{array}{r}0.8 \\
(0.7)\end{array}$ & $\begin{array}{l}-0.6^{*} \\
(0.3)\end{array}$ & $\begin{array}{l}-1.2^{*} \\
(0.7)\end{array}$ & $\begin{array}{l}-3.6^{* * *} \\
(1.1)\end{array}$ \\
\hline 13 months & $\begin{array}{l}3.0^{* * *} \\
(0.2)\end{array}$ & $\begin{array}{r}0.2 \\
(0.4)\end{array}$ & $\begin{array}{l}2.2^{* * * *} \\
(0.7)\end{array}$ & $\begin{array}{l}-0.2 \\
(0.3)\end{array}$ & $\begin{array}{r}0.3 \\
(0.6)\end{array}$ & $\begin{array}{r}-0.5 \\
(1.2)\end{array}$ \\
\hline
\end{tabular}

Notes: Sample restricted to stock purchases of at least $\$ 10,000$. The specification is:

$$
\operatorname{Sell}_{\mathrm{i}, \mathrm{t}}=\alpha_{\mathrm{t}}+\beta_{1, \mathrm{t}}{ }^{*} \operatorname{GAIN}_{\mathrm{i}, \mathrm{t}-1}+\beta_{2, \mathrm{t}}{ }^{*} \operatorname{LOSS}_{\mathrm{i}, \mathrm{t}-1}+\varepsilon_{\mathrm{i}, \mathrm{t}}
$$

where GAIN $=\max ($ return, 0$)$, LOSS $=\min ($ return, 0$)$. Standard errors (shown in parentheses) allow for heteroskedasticity as well as correlation across observations of the same household.

${ }^{* * * *},{ }^{* *},{ }^{*}$ denote significance at the 1 percent, 5 percent, and 10 percent levels, respectively. 
Table 4 - Cox Proportional Hazards Model of Stock Sales, Full Sample and Large Purchases (At Least \$10,000), With AND Without InVESTOR-SPECIFIC BaSELINE HaZARD

\begin{tabular}{|c|c|c|c|c|c|c|}
\hline & \multicolumn{3}{|c|}{ Full Sample } & \multicolumn{3}{|c|}{$\begin{array}{l}\text { Full Sample - } \\
\text { Investor-Specific Baseline }\end{array}$} \\
\hline & \multirow[b]{2}{*}{$\begin{array}{l}\text { Taxable } \\
\text { accounts }\end{array}$} & \multicolumn{2}{|c|}{ All accounts } & \multirow[b]{2}{*}{$\begin{array}{l}\text { Taxable } \\
\text { accounts }\end{array}$} & \multicolumn{2}{|c|}{ All accounts } \\
\hline & & $\begin{array}{c}\text { Tax- } \\
\text { deferred } \\
\text { accounts }\end{array}$ & $\begin{array}{l}\text { Interaction } \\
\text { w/ taxable } \\
\text { accounts }\end{array}$ & & $\begin{array}{c}\text { Tax- } \\
\text { deferred } \\
\text { accounts }\end{array}$ & $\begin{array}{l}\text { Interaction } \\
\text { w/ taxable } \\
\text { accounts }\end{array}$ \\
\hline \multirow{2}{*}{ GAIN } & $0.11^{* * *}$ & $0.09^{* * *}$ & $0.02^{*}$ & 0.21 & $0.27^{* * *}$ & $-0.05^{* *}$ \\
\hline & $(0.01)$ & $(0.01)$ & $(0.01)$ & $(0.01)$ & $(0.02)$ & $(0.02)$ \\
\hline \multirow[t]{2}{*}{ GAIN*December } & -0.02 & $0.07^{* * *}$ & $-0.09^{* * *}$ & $-0.06^{* *}$ & -0.02 & -0.04 \\
\hline & $(0.03)$ & $(0.02)$ & $(0.03)$ & $(0.04)$ & $(0.05)$ & $(0.06)$ \\
\hline \multirow[t]{2}{*}{ LOSS } & $1.03^{* * *}$ & $1.42^{* * *}$ & $-0.40^{* * *}$ & $1.38^{* * *}$ & $1.70^{* * *}$ & $-0.32^{* * *}$ \\
\hline & $(0.03)$ & $(0.03)$ & $(0.04)$ & $(0.03)$ & $(0.04)$ & $(0.05)$ \\
\hline \multirow[t]{2}{*}{ LOSS*December } & $-2.23^{* * *}$ & $-0.26^{* *}$ & $-1.97^{* * *}$ & $-2.35^{* * *}$ & $-0.23^{* *}$ & $-2.11^{* * *}$ \\
\hline & $(0.05)$ & $(0.11)$ & $(0.12)$ & $(0.06)$ & $(0.11)$ & $(0.13)$ \\
\hline \multirow[t]{5}{*}{ December } & $0.12^{* * *}$ & 0.01 & $0.11^{* * *}$ & $0.10^{* * *}$ & 0.03 & $0.07^{* * *}$ \\
\hline & $(0.01)$ & $(0.02)$ & $(0.02)$ & $(0.01)$ & $(0.02)$ & $(0.02)$ \\
\hline & \multicolumn{3}{|c|}{ Original Purchase at least $\$ 10,000$} & \multicolumn{3}{|c|}{$\begin{array}{c}\text { Original Purchase at least } \$ 10,000- \\
\text { Investor-Specific Baseline }\end{array}$} \\
\hline & \multirow{2}{*}{$\begin{array}{l}\text { Taxable } \\
\text { accounts }\end{array}$} & \multicolumn{2}{|c|}{ All accounts } & & \multicolumn{2}{|c|}{ All accounts } \\
\hline & & $\begin{array}{c}\text { Tax- } \\
\text { deferred } \\
\text { accounts }\end{array}$ & $\begin{array}{l}\text { Interaction } \\
\text { w/ taxable } \\
\text { accounts }\end{array}$ & $\begin{array}{l}\text { laxable } \\
\text { accounts }\end{array}$ & $\begin{array}{c}\text { Tax- } \\
\text { deferred } \\
\text { accounts }\end{array}$ & $\begin{array}{l}\text { Interaction } \\
\text { w/ taxable } \\
\text { accounts }\end{array}$ \\
\hline \multirow[t]{2}{*}{ GAIN } & -0.03 & $0.06^{* * *}$ & $-0.09^{* * *}$ & 0.11 & $0.37^{* * *}$ & $-0.26^{* * *}$ \\
\hline & $(0.02)$ & $(0.01)$ & $(0.03)$ & $(0.03)$ & $(0.05)$ & $(0.06)$ \\
\hline \multirow[t]{2}{*}{ GAIN*December } & -0.09 & $0.13^{* * *}$ & $-0.22^{* * *}$ & -0.03 & $0.32^{*}$ & $-0.35^{*}$ \\
\hline & $(0.08)$ & $(0.04)$ & $(0.09)_{* * *}$ & $(0.08)$ & $(0.18)$ & $(0.20)$ \\
\hline \multirow[t]{2}{*}{ LOSS } & $1.18^{* * *}$ & $1.65^{* * *}$ & $-0.46^{* * *}$ & $1.98^{* * *}$ & $2.04^{* * *}$ & -0.06 \\
\hline & $(0.06)$ & $(0.08)$ & $(0.10)$ & $(0.08)$ & $(0.11)$ & $(0.13)$ \\
\hline \multirow[t]{2}{*}{ LOSS*December } & $-2.72^{* * *}$ & -0.45 & $-2.27^{* * *}$ & $-2.98^{* * *}$ & $-0.66^{*}$ & $-2.33^{* * *}$ \\
\hline & $(0.12)$ & $(0.29)$ & $(0.32)$ & $(0.16)$ & $(0.37)$ & $(0.40)$ \\
\hline \multirow[t]{2}{*}{ December } & $0.14^{* * *}$ & -0.05 & $0.19^{* * *}$ & $0.11^{* * *}$ & $-0.13^{* * *}$ & $0.24^{* * *}$ \\
\hline & $(0.03)$ & $(0.04)$ & $(0.05)$ & $(0.03)$ & $(0.05)$ & $(0.06)$ \\
\hline
\end{tabular}

Notes: GAIN $=\max ($ return, 0$)$ and LOSS $=\min ($ return, 0$)$. Standard errors (shown in parentheses) allow for heteroskedasticity as well as correlation across observations of the same household.

${ }^{* * *},{ }^{* *},{ }^{*}$ denote significance at the 1 percent, 5 percent, and 10 percent levels, respectively. 
Table 5-Cox Proportional Hazards Model of Stock Sales, Stratified by Value of Stock Purchase

\begin{tabular}{|c|c|c|c|c|c|c|c|c|}
\hline & \multicolumn{4}{|c|}{ Model estimated for taxable accounts } & \multicolumn{4}{|c|}{$\begin{array}{l}\text { Model estimated for all accounts (effect of taxable } \\
\text { account relative to tax-deferred reported) }\end{array}$} \\
\hline & $\$ 0-2,499$ & $\$ 2,500-4,999$ & $\$ 5,000-9,999$ & $\$ 10,000+$ & $\$ 0-2,499$ & $\$ 2,500-4,999$ & $\$ 5,000-9,999$ & $\$ 10,000+$ \\
\hline GAIN & $\begin{array}{c}0.14^{* * *} \\
(0.01)\end{array}$ & $\begin{array}{c}0.15^{* * *} \\
(0.02)\end{array}$ & $\begin{array}{c}0.14^{* * *} \\
(0.01)\end{array}$ & $\begin{array}{r}-0.03 \\
(0.02)\end{array}$ & $\begin{array}{l}0.05^{* * *} \\
(0.02)\end{array}$ & $\begin{array}{r}0.02 \\
(0.03)\end{array}$ & $\begin{array}{l}-0.12^{* * *} \\
(0.03)\end{array}$ & $\begin{array}{l}-0.09^{* * *} \\
(0.03)\end{array}$ \\
\hline GAIN*December & $\begin{array}{l}-0.03 \\
(0.03)\end{array}$ & $\begin{array}{r}0.02 \\
(0.02)\end{array}$ & $\begin{array}{r}-0.05 \\
(0.06)\end{array}$ & $\begin{array}{l}-0.09 \\
(0.08)\end{array}$ & $\begin{array}{l}-0.10^{* * *} \\
(0.04)\end{array}$ & $\begin{array}{r}-0.04 \\
(0.04)\end{array}$ & $\begin{array}{r}0.10 \\
(0.09)\end{array}$ & $\begin{array}{l}-0.22^{* * *} \\
(0.09)\end{array}$ \\
\hline LOSS & $\begin{array}{l}1.02^{* * *} \\
(0.05)\end{array}$ & $\begin{array}{c}0.94^{* * *} \\
(0.05)\end{array}$ & $\begin{array}{c}0.91^{* * *} \\
(0.05)\end{array}$ & $\begin{array}{l}1.18^{* * *} \\
(0.06)\end{array}$ & $\begin{array}{l}-0.22^{* * *} \\
(0.07)\end{array}$ & $\begin{array}{l}-0.38^{* * *} \\
(0.08)\end{array}$ & $\begin{array}{l}-0.47^{* * *} \\
(0.09)\end{array}$ & $\begin{array}{l}-0.46^{* * *} \\
(0.10)\end{array}$ \\
\hline LOSS*December & $\begin{array}{l}-1.87^{* * *} \\
(0.09)\end{array}$ & $\begin{array}{l}-2.42^{* * *} \\
(0.10)\end{array}$ & $\begin{array}{l}-2.28^{* * *} \\
(0.11)\end{array}$ & $\begin{array}{l}-2.72^{* * *} \\
(0.12)\end{array}$ & $\begin{array}{l}-1.54^{* * *} \\
(0.19)\end{array}$ & $\begin{array}{l}-2.13^{* * *} \\
(0.23)\end{array}$ & $\begin{array}{l}-2.51^{* * *} \\
(0.29)\end{array}$ & $\begin{array}{l}-2.27^{* * *} \\
(0.32)\end{array}$ \\
\hline December & $\begin{array}{l}0.13^{* * *} \\
(0.03)\end{array}$ & $\begin{array}{c}0.05^{*} \\
(0.02)\end{array}$ & $\begin{array}{l}0.15^{* * *} \\
(0.03)\end{array}$ & $\begin{array}{c}0.14^{* * *} \\
(0.03)\end{array}$ & $\begin{array}{c}0.09^{* *} \\
(0.04)\end{array}$ & $\begin{array}{r}0.01 \\
(0.04)\end{array}$ & $\begin{array}{c}0.11^{* *} \\
(0.04)\end{array}$ & $\begin{array}{c}0.19^{* * *} \\
(0.05)\end{array}$ \\
\hline Number of Obs. & 965,998 & 976,613 & 829,498 & 677,422 & $1,836,721$ & $1,762,347$ & $1,395,918$ & $1,002,382$ \\
\hline
\end{tabular}

Notes: GAIN $=\max ($ return, 0$)$ and LOSS $=\min ($ return, 0$)$. The Cox proportional hazards model employs a non-parametric estimate of the baseline hazard, $\lambda_{0, i}(\mathrm{t})$, which denotes the probability of selling stock $\mathrm{t}$ months after purchase conditional on no prior sale. Standard errors (shown in parentheses) allow for heteroskedasticity as well as correlation across observations of the same household. ***,$\quad{ }^{* *}$, denote significance at the 1 percent, 5 percent, and 10 percent levels, respectively. 
Table 6 - Cox Proportional Hazards Model of Stock Sales, Stratified by Total Household Brokerage Account Value at End of Year Prior to Stock Purchase, Full SAMPle of StOck Purchases in Taxable Accounts

\begin{tabular}{|c|c|c|c|c|c|c|c|c|}
\hline \multirow[b]{3}{*}{ GAIN } & \multicolumn{8}{|c|}{ Total Household Brokerage Account Value (in \$000s) } \\
\hline & \multicolumn{2}{|c|}{$0-25$} & \multicolumn{2}{|c|}{$25-100$} & \multicolumn{2}{|c|}{$100+$} & \multicolumn{2}{|c|}{ All Households } \\
\hline & $\begin{array}{l}0.11^{* * * *} \\
(0.01)\end{array}$ & $\begin{array}{l}0.11^{* * *} \\
(0.01)\end{array}$ & $\begin{array}{l}0.15^{* * *} \\
(0.01)\end{array}$ & $\begin{array}{l}0.20^{* * *} \\
(0.01)\end{array}$ & $\begin{array}{l}0.15^{* * *} \\
(0.01)\end{array}$ & $\begin{array}{l}0.20^{* * *} \\
(0.02)\end{array}$ & $\begin{array}{l}0.15^{* * *} \\
(0.01)\end{array}$ & $\begin{array}{l}0.25^{* * *} \\
(0.01)\end{array}$ \\
\hline GAIN*December & $\begin{array}{r}0.01 \\
(0.02)\end{array}$ & $\begin{array}{r}0.01 \\
(0.02)\end{array}$ & $\begin{array}{r}-0.04 \\
(0.06)\end{array}$ & $\begin{array}{r}-0.04 \\
(0.06)\end{array}$ & $\begin{array}{r}-0.02 \\
(0.06)\end{array}$ & $\begin{array}{r}0.04 \\
(0.05)\end{array}$ & $\begin{array}{r}0.01 \\
(0.02)\end{array}$ & $\begin{array}{r}-0.03 \\
(0.04)\end{array}$ \\
\hline LOSS & $\begin{array}{l}1.40^{* * *} \\
(0.05)\end{array}$ & $\begin{array}{l}1.35^{* * *} \\
(0.06)\end{array}$ & $\begin{array}{l}1.09^{* * *} \\
(0.05)\end{array}$ & $\begin{array}{l}0.97^{* * *} \\
(0.05)\end{array}$ & $\begin{array}{l}0.72^{* * *} \\
(0.05)\end{array}$ & $\begin{array}{l}0.51^{* * *} \\
(0.06)\end{array}$ & $\begin{array}{l}0.96^{* * *} \\
(0.03)\end{array}$ & $\begin{array}{l}1.29^{* * *} \\
(0.04)\end{array}$ \\
\hline LOSS*December & $\begin{array}{l}-2.26^{* * *} \\
(0.10)\end{array}$ & $\begin{array}{l}-2.24^{* * *} \\
(0.10)\end{array}$ & $\begin{array}{l}-2.39^{* * *} \\
(0.10)\end{array}$ & $\begin{array}{l}-2.27^{* * *} \\
(0.11)\end{array}$ & $\begin{array}{l}-2.23^{* * *} \\
(0.10)\end{array}$ & $\begin{array}{l}-2.10^{* * *} \\
(0.12)\end{array}$ & $\begin{array}{l}-2.20^{* * *} \\
(0.06)\end{array}$ & $\begin{array}{l}-2.26^{* * *} \\
(0.08)\end{array}$ \\
\hline December & $\begin{array}{l}0.14^{* * *} \\
(0.03)\end{array}$ & $\begin{array}{l}0.13^{* * *} \\
(0.03)\end{array}$ & $\begin{array}{l}0.08^{* * *} \\
(0.03)\end{array}$ & $\begin{array}{l}0.08^{* * *} \\
(0.03)\end{array}$ & $\begin{array}{l}0.11^{* * *} \\
(0.03)\end{array}$ & $\begin{array}{c}0.08^{* * *} \\
(0.03)\end{array}$ & $\begin{array}{l}0.10^{* * *} \\
(0.02)\end{array}$ & $\begin{array}{c}0.09^{* * *} \\
(0.02)\end{array}$ \\
\hline $\begin{array}{l}\text { Interactions of Variables } \\
\quad G A I N\end{array}$ & h $\$ 10,000$ & $\begin{array}{c}\text { - Buy Indic } \\
-0.45^{* * *} \\
(0.09)\end{array}$ & & $\begin{array}{l}-0.41^{* * *} \\
(0.06)\end{array}$ & & $\begin{array}{l}-0.23^{* * *} \\
(0.04)\end{array}$ & $\begin{array}{l}-0.30^{* * *} \\
(0.03)\end{array}$ & $\begin{array}{l}-0.14^{* * *} \\
(0.03)\end{array}$ \\
\hline GAIN*December & & $\begin{array}{r}-0.09 \\
(0.30)\end{array}$ & & $\begin{array}{r}0.10 \\
(0.16)\end{array}$ & & $\begin{array}{l}-0.28^{*} \\
(0.17)\end{array}$ & $\begin{array}{l}-0.15 \\
(0.11)\end{array}$ & $\begin{array}{l}-0.04 \\
(0.10)\end{array}$ \\
\hline LOSS & & $\begin{array}{l}0.88^{* * *} \\
(0.22)\end{array}$ & & $\begin{array}{l}0.82^{* * *} \\
(0.15)\end{array}$ & & $\begin{array}{l}0.65^{* * *} \\
(0.11)\end{array}$ & $\begin{array}{l}-0.52^{* * *} \\
(0.08)\end{array}$ & $\begin{array}{l}0.61 \\
(0.09)\end{array}$ \\
\hline LOSS*December & & $\begin{array}{r}-0.54 \\
(0.43)\end{array}$ & & $\begin{array}{l}-0.89^{* * *} \\
(0.26)\end{array}$ & & $\begin{array}{l}-0.54^{* *} \\
(0.22)\end{array}$ & $\begin{array}{l}-0.59^{* * *} \\
(0.15)\end{array}$ & $\begin{array}{l}-0.89^{* * *} \\
(0.18)\end{array}$ \\
\hline December & & $\begin{array}{r}0.04 \\
(0.09)\end{array}$ & & $\begin{array}{r}-0.05 \\
(0.06)\end{array}$ & & $\begin{array}{r}0.06 \\
(0.05)\end{array}$ & $\begin{array}{r}0.02 \\
(0.04)\end{array}$ & $\begin{array}{r}-0.01 \\
(0.04)\end{array}$ \\
\hline $\begin{array}{l}\$ 10,000+ \\
\text { Buy indicator }\end{array}$ & & $\begin{array}{l}0.43^{* * *} \\
(0.03)\end{array}$ & & $\begin{array}{l}0.47^{* * *} \\
(0.02)\end{array}$ & & $\begin{array}{l}0.37^{* * *} \\
(0.02)\end{array}$ & $\begin{array}{l}0.32^{* * *} \\
(0.01)\end{array}$ & $\begin{array}{l}0.22^{* * *} \\
(0.01)^{2}\end{array}$ \\
\hline HH-specific baseline & No & No & No & No & No & No & No & Yes \\
\hline Number of Observations & \multicolumn{2}{|c|}{753,618} & \multicolumn{2}{|c|}{895,290} & \multicolumn{2}{|c|}{972,854} & \multicolumn{2}{|c|}{$2,621,762$} \\
\hline
\end{tabular}

Notes: GAIN $=\max ($ return, 0$)$ and LOSS $=\min ($ return, 0$)$. December is a dummy variable denoting the month of December. Standard errors (shown in parentheses) allow for heteroskedasticity as well as correlation across observations of the same household.

${ }^{* * *},{ }^{* *},{ }^{*}$ denote significance at the 1 percent, 5 percent, and 10 percent levels, respectively. 
Table 7-Cox Proportional Hazards Model of Stock Sales for Large Purchases (AT LEAST \$10,000)

\begin{tabular}{|c|c|c|c|}
\hline & \multirow[b]{2}{*}{$\begin{array}{l}\text { Taxable } \\
\text { accounts }\end{array}$} & \multicolumn{2}{|c|}{ All accounts } \\
\hline & & $\begin{array}{c}\text { Tax- } \\
\text { deferred } \\
\text { accounts }\end{array}$ & $\begin{array}{c}\text { Interaction } \\
\text { w/ taxable } \\
\text { accounts }\end{array}$ \\
\hline GAIN & $\begin{array}{l}-0.24^{* * *} \\
(0.04)\end{array}$ & $\begin{array}{r}-0.01 \\
(0.03)\end{array}$ & $\begin{array}{l}-0.23^{* * *} \\
(0.05)\end{array}$ \\
\hline GAIN*(within 6 months after purchase) & $\begin{array}{c}0.79^{* * *} \\
(0.06)\end{array}$ & $\begin{array}{c}0.99^{* * *} \\
(0.09)\end{array}$ & $\begin{array}{c}-0.20^{*} \\
(0.11)\end{array}$ \\
\hline GAIN $*($ months $7-12$ after purchase) & $\begin{array}{c}0.29^{* * *} \\
(0.06)\end{array}$ & $\begin{array}{c}0.35^{\text {*** }} \\
(0.05)\end{array}$ & $\begin{array}{r}-0.06 \\
(0.08)\end{array}$ \\
\hline GAIN*December & $\begin{array}{r}-0.08 \\
(0.15)\end{array}$ & $\begin{array}{r}0.10 \\
(0.08)\end{array}$ & $\begin{array}{l}-0.17 \\
(0.17)\end{array}$ \\
\hline GAIN*Dec*(within 6 months after purchase) & $\begin{array}{r}0.34 \\
(0.23)\end{array}$ & $\begin{array}{l}-0.03 \\
(0.19)\end{array}$ & $\begin{array}{r}0.37 \\
(0.29)\end{array}$ \\
\hline GAIN*Dec*(months $7-12$ after purchase) & $\begin{array}{r}-0.15 \\
(0.26)\end{array}$ & $\begin{array}{r}0.12 \\
(0.23)\end{array}$ & $\begin{array}{r}-0.27 \\
(0.35)\end{array}$ \\
\hline LOSS & $\begin{array}{c}0.86^{* * *} \\
(0.10)\end{array}$ & $\begin{array}{l}1.09^{* * *} \\
(0.12)\end{array}$ & $\begin{array}{l}-0.23 \\
(0.16)\end{array}$ \\
\hline LOSS*(within 6 months after purchase) & $\begin{array}{c}0.74^{* * *} \\
(0.14)\end{array}$ & $\begin{array}{c}0.60^{\text {*** }} \\
(0.19)\end{array}$ & $\begin{array}{r}0.15 \\
(0.24)\end{array}$ \\
\hline LOSS*(months $7-12$ after purchase) & $\begin{array}{r}0.03 \\
(0.15)\end{array}$ & $\begin{array}{c}0.63^{* * *} \\
(0.21)\end{array}$ & $\begin{array}{l}-0.60^{* *} \\
(0.26)\end{array}$ \\
\hline LOSS*December & $\begin{array}{l}-2.59^{* * *} \\
(0.20)\end{array}$ & $\begin{array}{l}-1.03^{* * *} \\
(0.35)\end{array}$ & $\begin{array}{l}-1.55^{* * *} \\
(0.40)\end{array}$ \\
\hline LOSS*Dec*(within 6 months after purchase) & $\begin{array}{r}-0.23 \\
(0.31)\end{array}$ & $\begin{array}{c}1.59^{\text {*** }} \\
(0.65)\end{array}$ & $\begin{array}{l}-1.82^{* * *} \\
(0.72)\end{array}$ \\
\hline LOSS*Dec*(months $7-12$ after purchase) & $\begin{array}{c}-0.14 \\
(0.30)\end{array}$ & $\begin{array}{r}0.72 \\
(0.73)\end{array}$ & $\begin{array}{r}-0.86 \\
(0.79)\end{array}$ \\
\hline December & $\begin{array}{r}-0.00 \\
(0.08)\end{array}$ & $\begin{array}{r}-0.14 \\
(0.09)\end{array}$ & $\begin{array}{r}0.13 \\
(0.12)\end{array}$ \\
\hline December*(within 6 months after purchase) & $\begin{array}{r}0.15^{*} \\
(0.08)\end{array}$ & $\begin{array}{r}0.19^{*} \\
(0.11)\end{array}$ & $\begin{array}{r}-0.04 \\
(0.13)\end{array}$ \\
\hline December*(months $7-12$ after purchase) & $\begin{array}{c}0.20^{* *} \\
(0.10)\end{array}$ & $\begin{array}{r}-0.04 \\
(0.13)\end{array}$ & $\begin{array}{r}0.24 \\
(0.17)\end{array}$ \\
\hline Number of Observations & 677,422 & & 382 \\
\hline
\end{tabular}

Notes: GAIN $=\max ($ return, 0$)$ and LOSS $=\min ($ return, 0$)$. The Cox proportional hazards model employs a non-parametric estimate of the baseline hazard. Standard errors (shown in parentheses) allow for heteroskedasticity as well as correlation across observations of the same household.

${ }^{* * *},{ }^{* *},{ }^{*}$ denote significance at the 1 percent, 5 percent, and 10 percent levels, respectively. 
TABle 8 - Cox Proportional Hazards Model of Stock Sales, Controlling For Volatility, FOR LARGE PURCHASES (AT LEAST \$10,000)

\begin{tabular}{|c|c|c|c|c|c|c|}
\hline & \multirow[b]{2}{*}{$\begin{array}{c}\text { Taxable } \\
\text { accounts }\end{array}$} & \multicolumn{2}{|c|}{ All accounts } & \multirow[b]{2}{*}{$\begin{array}{l}\text { Taxable } \\
\text { accounts }\end{array}$} & \multicolumn{2}{|c|}{ All accounts } \\
\hline & & $\begin{array}{c}\text { Tax- } \\
\text { deferred } \\
\text { accounts }\end{array}$ & $\begin{array}{c}\text { Interaction } \\
\text { w/ taxable } \\
\text { accounts }\end{array}$ & & $\begin{array}{l}\text { Tax- } \\
\text { deferred } \\
\text { accounts }\end{array}$ & $\begin{array}{l}\text { Interaction } \\
\text { w/ taxable } \\
\text { accounts }\end{array}$ \\
\hline GAIN & $\begin{array}{l}-0.26^{* * *} \\
(0.03)\end{array}$ & $\begin{array}{r}0.02 \\
(0.02)\end{array}$ & $\begin{array}{l}-0.27^{\text {*** }} \\
(0.04)\end{array}$ & $\begin{array}{l}-0.33^{* * *} \\
(0.05)\end{array}$ & $\begin{array}{l}-0.14^{* * *} \\
(0.05)\end{array}$ & $\begin{array}{l}-0.19^{* * *} \\
(0.07)\end{array}$ \\
\hline $\begin{array}{l}\text { GAIN* } \\
\text { (w/in } 6 \text { mos after purchase) }\end{array}$ & & & & $\begin{array}{l}0.51^{* * *} \\
(0.08)\end{array}$ & $\begin{array}{l}0.78^{* * *} \\
(0.10)\end{array}$ & $\begin{array}{l}-0.26^{* *} \\
(0.12)\end{array}$ \\
\hline $\begin{array}{l}\text { GAIN* } \\
\text { (mos } 7 \text { - } 12 \text { after purchase) }\end{array}$ & & & & $\begin{array}{r}0.15^{*} \\
(0.09)\end{array}$ & $\begin{array}{l}0.30^{* * *} \\
(0.07)\end{array}$ & $\begin{array}{r}-0.16 \\
(0.11)\end{array}$ \\
\hline GAIN*December & $\begin{array}{l}-0.28^{* * *} \\
(0.11)\end{array}$ & $\begin{array}{l}-0.03 \\
(0.10)\end{array}$ & $\begin{array}{l}-0.25^{*} \\
(0.14)\end{array}$ & $\begin{array}{r}-0.22 \\
(0.16)\end{array}$ & $\begin{array}{r}0.10 \\
(0.13)\end{array}$ & $\begin{array}{l}-0.32 \\
(0.21)\end{array}$ \\
\hline LOSS & $\begin{array}{l}1.17^{* * *} \\
(0.09)\end{array}$ & $\begin{array}{l}1.45^{* * *} \\
(0.11)\end{array}$ & $\begin{array}{l}-0.28^{* *} \\
(0.14)\end{array}$ & $\begin{array}{l}0.86^{* * *} \\
(0.15)\end{array}$ & $\begin{array}{l}1.18^{* * *} \\
(0.19)\end{array}$ & $\begin{array}{l}-0.33 \\
(0.24)\end{array}$ \\
\hline $\begin{array}{l}\text { LOSS* } \\
\text { (w/in } 6 \text { mos after purchase) }\end{array}$ & & & & $\begin{array}{l}1.03^{* * *} \\
(0.21)^{2}\end{array}$ & $\begin{array}{l}0.62^{* *} \\
(0.27)\end{array}$ & $\begin{array}{r}0.42 \\
(0.34)\end{array}$ \\
\hline $\begin{array}{l}\text { LOSS* } \\
\text { (mos } 7 \text { - } 12 \text { after purchase) }\end{array}$ & & & & $\begin{array}{r}0.06 \\
(0.23)\end{array}$ & $\begin{array}{c}0.51^{*} \\
(0.30)\end{array}$ & $\begin{array}{r}-0.45 \\
(0.38)\end{array}$ \\
\hline LOSS*December & $\begin{array}{l}-2.67^{* * *} \\
(0.13)\end{array}$ & $\begin{array}{l}-0.51^{*} \\
(0.30)\end{array}$ & $\begin{array}{l}-2.16^{* * *} \\
(0.33)\end{array}$ & $\begin{array}{l}-2.50^{* * *} \\
(0.22)\end{array}$ & $\begin{array}{l}-1.13^{* * *} \\
(0.38)\end{array}$ & $\begin{array}{l}-1.37^{* * *} \\
(0.43)\end{array}$ \\
\hline Volatility*(Have Gain) & $\begin{array}{l}3.73^{* * *} \\
(0.13)\end{array}$ & $\begin{array}{l}3.96^{* * *} \\
(0.17)\end{array}$ & $\begin{array}{r}-0.23 \\
(0.21)\end{array}$ & $\begin{array}{l}1.69^{* * *} \\
(0.35)\end{array}$ & $\begin{array}{l}3.60^{* * *} \\
(0.41)\end{array}$ & $\begin{array}{l}-1.92^{* * *} \\
(0.54)\end{array}$ \\
\hline $\begin{array}{l}\text { Volatility*(Have Gain)* } \\
\text { (w/in } 6 \text { mos after purchase) }\end{array}$ & & & & $\begin{array}{l}2.03^{* * *} \\
(0.37)\end{array}$ & $\begin{array}{r}-0.33 \\
(0.43)\end{array}$ & $\begin{array}{l}2.35^{* * *} \\
(0.57)\end{array}$ \\
\hline $\begin{array}{l}\text { Volatility*(Have Gain)* } \\
\text { (mos } 7-12 \text { after purchase) }\end{array}$ & & & & $\begin{array}{l}2.10^{* * *} \\
(0.44)\end{array}$ & $\begin{array}{r}0.82^{*} \\
(0.50)\end{array}$ & $\begin{array}{l}1.28^{* *} \\
(0.67)\end{array}$ \\
\hline Volatility*(Have Loss) & $\begin{array}{l}-1.79^{* * *} \\
(0.14)\end{array}$ & $\begin{array}{l}-2.09^{* * *} \\
(0.18)\end{array}$ & $\begin{array}{r}0.30 \\
(0.23)\end{array}$ & $\begin{array}{l}-1.09^{* * *} \\
(0.43)\end{array}$ & $\begin{array}{l}-1.89^{* * *} \\
(0.53)\end{array}$ & $\begin{array}{r}0.80 \\
(0.68)\end{array}$ \\
\hline $\begin{array}{l}\text { Volatility*(Have Loss)* } \\
\text { (w/in } 6 \text { mos after purchase) }\end{array}$ & & & & $\begin{array}{r}0.03 \\
(0.47)\end{array}$ & $\begin{array}{r}0.71 \\
(0.58)\end{array}$ & $\begin{array}{l}-0.67 \\
(0.74)\end{array}$ \\
\hline $\begin{array}{l}\text { Volatility*(Have Loss)* } \\
\text { (mos } 7-12 \text { after purchase) }\end{array}$ & & & & $\begin{array}{r}-0.80 \\
(0.57)\end{array}$ & $\begin{array}{l}-0.16 \\
(0.69)\end{array}$ & $\begin{array}{r}-0.64 \\
(0.90)\end{array}$ \\
\hline Number of Observations & 617,031 & 915 & 284 & 617,031 & & 5,284 \\
\hline
\end{tabular}

Notes: GAIN $=\max ($ return, 0$)$ and LOSS $=\min ($ return, 0$)$. The Cox proportional hazards model employs a non-parametric estimate of the baseline hazard. Standard errors (shown in parentheses) allow for heteroskedasticity as well as correlation across observations of the same household.

${ }^{* * *},{ }^{* *},{ }^{*}$ denote significance at the 1 percent, 5 percent, and 10 percent levels, respectively. 
TABle 9-Cox Proportional Hazards Model of Stock SALES With INVESTOR-SpecifiC OR STOCK-SPECIFIC BASELINE HAZARDS FOR LARGE PURCHASES (AT LEAST \$10,000)

\begin{tabular}{|c|c|c|c|c|c|c|}
\hline & \multicolumn{3}{|c|}{ Investor-Specific Baselines } & \multicolumn{3}{|c|}{ Stock-Specific Baselines } \\
\hline & \multirow[b]{2}{*}{$\begin{array}{l}\text { Taxable } \\
\text { accounts }\end{array}$} & \multicolumn{2}{|c|}{ All accounts } & \multirow[b]{2}{*}{$\begin{array}{l}\text { Taxable } \\
\text { accounts }\end{array}$} & \multicolumn{2}{|c|}{ All accounts } \\
\hline & & $\begin{array}{l}\text { Tax- } \\
\text { deferred } \\
\text { accounts }\end{array}$ & $\begin{array}{l}\text { Interaction } \\
\text { w/ taxable } \\
\text { accounts }\end{array}$ & & $\begin{array}{l}\text { Tax- } \\
\text { deferred } \\
\text { accounts }\end{array}$ & $\begin{array}{l}\text { Interaction } \\
\text { w/ taxable } \\
\text { accounts }\end{array}$ \\
\hline GAIN & $\begin{array}{c}-0.09^{*} \\
(0.05)\end{array}$ & $\begin{array}{r}0.01 \\
(0.05)\end{array}$ & $\begin{array}{r}-0.10 \\
(0.07)\end{array}$ & $\begin{array}{l}-0.24^{* * *} \\
(0.06)\end{array}$ & $\begin{array}{c}-0.06 \\
(0.08)\end{array}$ & $\begin{array}{c}-0.17^{*} \\
(0.10)\end{array}$ \\
\hline $\begin{array}{l}\text { GAIN* } \\
\text { (w/in } 6 \text { mos after purchase) }\end{array}$ & $\begin{array}{l}0.83^{* * *} \\
(0.08)\end{array}$ & $\begin{array}{l}1.20^{* * *} \\
(0.10)\end{array}$ & $\begin{array}{l}-0.37^{* * *} \\
(0.13)\end{array}$ & $\begin{array}{l}0.48^{* * *} \\
(0.09)\end{array}$ & $\begin{array}{l}0.79^{* * *} \\
(0.12)\end{array}$ & $\begin{array}{l}-0.31^{* *} \\
(0.15)\end{array}$ \\
\hline $\begin{array}{l}\text { GAIN* } \\
\text { (mos } 7-12 \text { after purchase) }\end{array}$ & $\begin{array}{l}0.18^{* *} \\
(0.08)\end{array}$ & $\begin{array}{l}0.30^{* * *} \\
(0.11)\end{array}$ & $\begin{array}{r}-0.12 \\
(0.14)\end{array}$ & $\begin{array}{r}0.20^{* *} \\
(0.09)\end{array}$ & $\begin{array}{l}0.41^{* * *} \\
(0.12)\end{array}$ & $\begin{array}{r}-0.21 \\
(0.15)\end{array}$ \\
\hline GAIN*December & $\begin{array}{r}-0.03 \\
(0.14)\end{array}$ & $\begin{array}{r}0.56^{*} \\
(0.33)\end{array}$ & $\begin{array}{l}-0.59^{*} \\
(0.35)\end{array}$ & $\begin{array}{r}0.05 \\
(0.17)\end{array}$ & $\begin{array}{r}0.20 \\
(0.25)\end{array}$ & $\begin{array}{l}-0.16 \\
(0.30)\end{array}$ \\
\hline $\begin{array}{l}\text { GAIN*December } * \\
\text { (w/in } 6 \text { mos after purchase) }\end{array}$ & $\begin{array}{r}0.09 \\
(0.23)\end{array}$ & $\begin{array}{l}-0.49 \\
(0.44)\end{array}$ & $\begin{array}{r}0.58 \\
(0.50)\end{array}$ & $\begin{array}{r}0.11 \\
(0.26)\end{array}$ & $\begin{array}{l}-0.43 \\
(0.35)\end{array}$ & $\begin{array}{r}0.54 \\
(0.43)\end{array}$ \\
\hline $\begin{array}{l}\text { GAIN*December } * \\
(\text { mos } 7-12 \text { after purchase) }\end{array}$ & $\begin{array}{r}-0.21 \\
(0.31)\end{array}$ & $\begin{array}{l}-0.40 \\
(0.51)\end{array}$ & $\begin{array}{r}0.19 \\
(0.59)\end{array}$ & $\begin{array}{r}-0.28 \\
(0.31)\end{array}$ & $\begin{array}{r}-0.14 \\
(0.40)\end{array}$ & $\begin{array}{r}-0.14 \\
(0.50)\end{array}$ \\
\hline LOSS & $\begin{array}{l}1.08^{* * *} \\
(0.14)\end{array}$ & $\begin{array}{l}1.05^{* * *} \\
(0.17)\end{array}$ & $\begin{array}{r}0.04 \\
(0.22)\end{array}$ & $\begin{array}{l}1.36^{* * *} \\
(0.16)\end{array}$ & $\begin{array}{l}1.87^{* * *} \\
(0.21)\end{array}$ & $\begin{array}{l}-0.51^{* *} \\
(0.26)\end{array}$ \\
\hline $\begin{array}{l}\text { LOSS* } \\
\text { (w/in } 6 \text { mos after purchase) }\end{array}$ & $\begin{array}{l}1.51^{* * *} \\
(0.18)\end{array}$ & $\begin{array}{l}1.27^{* * *} \\
(0.23)\end{array}$ & $\begin{array}{r}0.25 \\
(0.30)\end{array}$ & $\begin{array}{l}1.28^{* * *} \\
(0.20)\end{array}$ & $\begin{array}{l}0.80^{* * *} \\
(0.26)\end{array}$ & $\begin{array}{r}0.48 \\
(0.33)\end{array}$ \\
\hline $\begin{array}{l}\text { LOSS* } \\
\text { (mos } 7-12 \text { after purchase) }\end{array}$ & $\begin{array}{l}0.40^{* *} \\
(0.20)\end{array}$ & $\begin{array}{l}1.05^{* * *} \\
(0.27)\end{array}$ & $\begin{array}{l}-0.65^{* *} \\
(0.34)\end{array}$ & $\begin{array}{r}0.16 \\
(0.22)\end{array}$ & $\begin{array}{r}0.51 \\
(0.31)\end{array}$ & $\begin{array}{r}-0.35 \\
(0.39)\end{array}$ \\
\hline LOSS*December & $\begin{array}{l}-2.45^{* * *} \\
(0.29)\end{array}$ & $\begin{array}{l}-1.54^{* * *} \\
(0.61)\end{array}$ & $\begin{array}{r}-0.91 \\
(0.68)\end{array}$ & $\begin{array}{l}-3.00^{* * *} \\
(0.30)\end{array}$ & $\begin{array}{l}-1.13^{* *} \\
(0.48)\end{array}$ & $\begin{array}{l}-1.87^{* * *} \\
(0.57)\end{array}$ \\
\hline $\begin{array}{l}\text { LOSS } * \text { December } * \\
\text { (w/in } 6 \text { mos after purchase) }\end{array}$ & $\begin{array}{r}-0.40 \\
(0.40)\end{array}$ & $\begin{array}{r}1.38^{*} \\
(0.83)\end{array}$ & $\begin{array}{l}-1.78^{* *} \\
(0.92)\end{array}$ & $\begin{array}{r}-0.16 \\
(0.41)\end{array}$ & $\begin{array}{l}2.02^{* * *} \\
(0.75)\end{array}$ & $\begin{array}{l}-2.18^{* * *} \\
(0.86)\end{array}$ \\
\hline $\begin{array}{l}\text { LOSS } * \text { December } * \\
\text { (mos } 7-12 \text { after purchase) }\end{array}$ & $\begin{array}{l}-0.73^{*} \\
(0.42)\end{array}$ & $\begin{array}{r}0.89 \\
(0.95)\end{array}$ & $\begin{array}{r}-1.62 \\
(1.04)\end{array}$ & $\begin{array}{r}0.02 \\
(0.45)\end{array}$ & $\begin{array}{r}1.04 \\
(0.88)\end{array}$ & $\begin{array}{r}-1.03 \\
(0.99)\end{array}$ \\
\hline December & $\begin{array}{r}0.07 \\
(0.09)\end{array}$ & $\begin{array}{l}-0.33^{* *} \\
(0.15)\end{array}$ & $\begin{array}{l}0.40^{* *} \\
(0.18)\end{array}$ & $\begin{array}{r}-0.06 \\
(0.09)\end{array}$ & $\begin{array}{r}-0.19 \\
(0.13)\end{array}$ & $\begin{array}{r}0.13 \\
(0.15)\end{array}$ \\
\hline $\begin{array}{l}\text { December * } \\
\text { (w/in } 6 \text { mos after purchase) }\end{array}$ & $\begin{array}{r}0.07 \\
(0.10)\end{array}$ & $\begin{array}{r}0.29^{*} \\
(0.16)\end{array}$ & $\begin{array}{r}-0.22 \\
(0.19)\end{array}$ & $\begin{array}{r}0.18^{*} \\
(0.10)\end{array}$ & $\begin{array}{l}0.29^{* *} \\
(0.14)\end{array}$ & $\begin{array}{l}-0.11 \\
(0.17)\end{array}$ \\
\hline $\begin{array}{l}\text { December } * \\
(\text { mos } 7-12 \text { after purchase) }\end{array}$ & $\begin{array}{r}0.05 \\
(0.12)\end{array}$ & $\begin{array}{r}0.07 \\
(0.20)\end{array}$ & $\begin{array}{r}-0.02 \\
(0.23)\end{array}$ & $\begin{array}{l}0.24^{* *} \\
(0.12)\end{array}$ & $\begin{array}{r}0.10 \\
(0.17)\end{array}$ & $\begin{array}{r}0.13 \\
(0.21)\end{array}$ \\
\hline Number of Observations & 677,422 & 1,002 & ,382 & 677,422 & 1,00 & 2,382 \\
\hline
\end{tabular}

Notes: GAIN $=\max ($ return, 0$)$ and LOSS $=\min ($ return, 0$)$. The Cox proportional hazards model employs a non-parametric estimate of the baseline hazard. Standard errors (shown in parentheses) allow for heteroskedasticity as well as correlation across observations of the same household.

***, ${ }^{* *},{ }^{*}$ denote significance at the 1 percent, 5 percent, and 10 percent levels, respectively. 
TABle 10 - Cox Proportional Hazards Model of Stock Sales With Household-

SPECIFIC AND FIRM-SPECIFIC BASELINE HAZARDS, SAMPLE RESTRICTED TO 100 MOSTPurchased StOcks in TAXABle ACCOUNTS AND LARGE PURCHASES (AT LEAST \$10,000)

\begin{tabular}{|c|c|c|c|c|c|c|}
\hline & \multirow[b]{2}{*}{$\begin{array}{l}\text { Taxable } \\
\text { accounts }\end{array}$} & \multicolumn{2}{|c|}{ All accounts } & \multirow[b]{2}{*}{$\begin{array}{l}\text { Taxable } \\
\text { accounts }\end{array}$} & \multicolumn{2}{|c|}{ All accounts } \\
\hline & & $\begin{array}{l}\text { Tax- } \\
\text { deferred } \\
\text { accounts }\end{array}$ & $\begin{array}{l}\text { Interaction } \\
\text { w/ taxable } \\
\text { accounts }\end{array}$ & & $\begin{array}{l}\text { Tax- } \\
\text { deferred } \\
\text { accounts }\end{array}$ & $\begin{array}{l}\text { Interaction } \\
\text { w/ taxable } \\
\text { accounts }\end{array}$ \\
\hline GAIN & $\begin{array}{r}0.01 \\
(0.06)\end{array}$ & $\begin{array}{l}0.31^{* * *} \\
(0.12)\end{array}$ & $\begin{array}{l}-0.30^{* *} \\
(0.14)\end{array}$ & $\begin{array}{r}-0.05 \\
(0.10)\end{array}$ & $\begin{array}{l}-0.17 \\
1(0.12)\end{array}$ & $\begin{array}{r}0.12 \\
(0.16)\end{array}$ \\
\hline $\begin{array}{l}\text { GAIN* } \\
\text { (w/in } 6 \text { mos after purchase) }\end{array}$ & & & & $\begin{array}{l}0.52^{* * *} \\
(0.16)\end{array}$ & $\begin{array}{l}1.24^{* * *} \\
(0.21)\end{array}$ & $\begin{array}{l}-0.71^{* * *} \\
(0.27)\end{array}$ \\
\hline $\begin{array}{l}\text { GAIN* } \\
\text { (mos } 7-12 \text { after purchase) }\end{array}$ & & & & $\begin{array}{r}0.10 \\
(0.14)\end{array}$ & $\begin{array}{l}0.80^{* * *} \\
(0.21)\end{array}$ & $\begin{array}{l}-0.70^{* * *} \\
(0.25)\end{array}$ \\
\hline GAIN*December & $\begin{array}{l}-0.25 \\
(0.20)\end{array}$ & $\begin{array}{r}-0.09 \\
(0.32)\end{array}$ & $\begin{array}{l}-0.16 \\
(0.37)\end{array}$ & $\begin{array}{l}-0.37 \\
(0.29)\end{array}$ & $\begin{array}{l}1.20^{* * *} \\
1(0.45)\end{array}$ & $\begin{array}{l}-1.57^{* * *} \\
(0.54)\end{array}$ \\
\hline $\begin{array}{l}\text { GAIN*December } * \\
\text { (w/in } 6 \text { mos after purchase) }\end{array}$ & & & & $\begin{array}{r}0.40 \\
(0.57)\end{array}$ & $\begin{array}{l}1-2.72^{* * *} \\
(0.95)\end{array}$ & $\begin{array}{l}3.12^{* * *} \\
(1.09)\end{array}$ \\
\hline $\begin{array}{l}\text { GAIN*December } * \\
(\operatorname{mos} 7-12 \text { after purchase) }\end{array}$ & & & & $\begin{array}{r}0.08 \\
(0.61)\end{array}$ & $\begin{array}{l}-2.50 \\
(0.79)\end{array}$ & $\begin{array}{l}2.58^{* * *} \\
(1.00)\end{array}$ \\
\hline LOSS & $\begin{array}{l}2.98^{* * *} \\
(0.17)\end{array}$ & $\begin{array}{l}2.77^{* * *} \\
(0.23)\end{array}$ & $\begin{array}{r}0.21 \\
(0.29)\end{array}$ & $\begin{array}{l}1.18^{* * *} \\
(0.28)\end{array}$ & $\begin{array}{l}0.96^{* * *} \\
(0.39)\end{array}$ & $\begin{array}{r}0.22 \\
(0.48)\end{array}$ \\
\hline $\begin{array}{l}\text { LOSS* } \\
\text { (w/in } 6 \text { mos after purchase) }\end{array}$ & & & & $\begin{array}{l}3.21^{* * *} \\
(0.38)\end{array}$ & $\begin{array}{l}2.34^{* * *} \\
(0.49)\end{array}$ & $\begin{array}{r}0.87 \\
(0.62)\end{array}$ \\
\hline $\begin{array}{l}\text { LOSS* } \\
\text { (mos } 7-12 \text { after purchase) }\end{array}$ & & & & $\begin{array}{r}0.69^{*} \\
(0.41)\end{array}$ & $\begin{array}{l}1.65^{* * *} \\
(0.56)\end{array}$ & $\begin{array}{r}-0.96 \\
(0.69)\end{array}$ \\
\hline LOSS*December & $\begin{array}{l}-3.60^{* * *} \\
(0.34)\end{array}$ & $\begin{array}{r}1.52^{*} \\
(0.84)\end{array}$ & $\begin{array}{l}-5.13^{* * *} \\
(0.91)\end{array}$ & $\begin{array}{l}-1.68^{* * *} \\
(0.61)\end{array}$ & $\begin{array}{c}-1.11 \\
(1.28)\end{array}$ & $\begin{array}{r}-0.57 \\
(1.42)\end{array}$ \\
\hline $\begin{array}{l}\text { LOSS*December } * \\
\text { (w/in } 6 \text { mos after purchase) }\end{array}$ & & & & $\begin{array}{l}-2.50^{* * *} \\
(0.81)\end{array}$ & $\begin{array}{c}4.38^{* *} \\
(1.87)\end{array}$ & $\begin{array}{l}-6.88^{* * *} \\
(2.04)\end{array}$ \\
\hline $\begin{array}{l}\text { LOSS*December * } \\
\text { (mos } 7-12 \text { after purchase) }\end{array}$ & & & & $\begin{array}{l}-2.90^{* * *} \\
(0.98)\end{array}$ & $\begin{array}{l}4.55^{* *} \\
(1.99)\end{array}$ & $\begin{array}{l}-7.45^{* * *} \\
(2.22)\end{array}$ \\
\hline December & $\begin{array}{l}0.15^{* * *} \\
(0.05)\end{array}$ & $\begin{array}{r}0.02 \\
(0.08)\end{array}$ & $\begin{array}{r}0.13 \\
(0.10)\end{array}$ & $\begin{array}{r}0.27 \\
(0.18)\end{array}$ & $\begin{array}{r}1 \quad-0.29 \\
(0.28)\end{array}$ & $\begin{array}{r}0.55^{*} \\
(0.33)\end{array}$ \\
\hline $\begin{array}{l}\text { December } * \\
\text { (w/in } 6 \text { mos after purchase) }\end{array}$ & & & & $\begin{array}{l}-0.15 \\
(0.19)\end{array}$ & $\begin{array}{r}0.42 \\
1(0.30)\end{array}$ & $\begin{array}{r}-0.57 \\
(0.35)\end{array}$ \\
\hline $\begin{array}{l}\text { December } * \\
\text { (mos } 7-12 \text { after purchase) }\end{array}$ & & & & $\begin{array}{r}-0.13 \\
(0.23)\end{array}$ & $\begin{array}{c}0.63^{*} \\
1(0.35)\end{array}$ & $\begin{array}{l}-0.75^{*} \\
(0.42)\end{array}$ \\
\hline Number of Observations & 281,290 & 417 & & 28,290 & & 7,594 \\
\hline
\end{tabular}

Notes: GAIN $=\max ($ return, 0$)$ and LOSS $=\min ($ return, 0$)$. The Cox proportional hazards model employs a non-parametric estimate of the baseline hazard. Standard errors (shown in parentheses) allow for heteroskedasticity as well as correlation across observations of the same household.

*** $,{ }^{* * *},{ }^{*}$ denote significance at the 1 percent, 5 percent, and 10 percent levels, respectively. 
Table 11-Regression of Probability of Selling Stock in December on Prior Performance Interacted With Household's CAPITAL Gain/LOSS REAlizations During CALENDAR YEAR AND MARKET PERFORMANCE DuRING CALENDAR YEAR, FOR LARGE PURCHASES (AT LEAST \$10,000)

\begin{tabular}{|c|c|c|c|c|c|c|c|c|c|c|c|c|}
\hline & \multicolumn{6}{|c|}{ Probability sell taxable-account stock (in percent) } & \multicolumn{6}{|c|}{$\begin{array}{l}\text { Probability of selling stock in taxable account relative to } \\
\text { selling stock in tax-deferred account (in percent) }\end{array}$} \\
\hline & \multicolumn{3}{|c|}{ December: All Month } & \multicolumn{3}{|c|}{ December: Last Week } & \multicolumn{3}{|c|}{ December: All Month } & \multicolumn{3}{|c|}{ December: Last Week } \\
\hline & $(1)$ & $(2)$ & $(3)$ & $(4)$ & $(5)$ & $(6)$ & $(7)$ & $(8)$ & $(9)$ & $(10)$ & $(11)$ & $(12)$ \\
\hline Constant & $\begin{array}{l}8.8^{* * *} \\
(0.4)\end{array}$ & $\begin{array}{l}5.2^{* * *} \\
(0.4)\end{array}$ & $\begin{array}{l}8.5^{* * *} \\
(0.4)\end{array}$ & $\begin{array}{l}10.2^{* * * *} \\
(0.8)\end{array}$ & $\begin{array}{l}7.7^{* * *} \\
(1.0)\end{array}$ & $\begin{array}{l}9.0^{* * *} \\
(1.0)\end{array}$ & $\begin{array}{r}1.0^{*} \\
(0.5)\end{array}$ & $\begin{array}{l}-1.2^{*} \\
(0.7)\end{array}$ & $\begin{array}{r}0.7 \\
(0.6)\end{array}$ & $\begin{array}{r}1.9 \\
(1.2)\end{array}$ & $\begin{array}{r}1.1 \\
(1.6)\end{array}$ & $\begin{array}{r}1.8 \\
(1.5)\end{array}$ \\
\hline GAIN & $\begin{array}{l}-5.4^{* * *} \\
(1.0)\end{array}$ & $\begin{array}{r}-1.6 \\
(1.0)\end{array}$ & $\begin{array}{l}-3.9^{* * *} \\
(1.0)\end{array}$ & $\begin{array}{l}-8.7^{* * *} \\
(2.0)\end{array}$ & $\begin{array}{l}-5.3^{* *} \\
(2.6)\end{array}$ & $\begin{array}{l}-4.2^{* *} \\
(1.8)\end{array}$ & $\begin{array}{l}-5.0^{* * *} \\
(1.8)\end{array}$ & $\begin{array}{r}-2.3 \\
(2.1)\end{array}$ & $\begin{array}{l}-3.7^{* *} \\
(1.9)\end{array}$ & $\begin{array}{r}-3.3 \\
(3.8)\end{array}$ & $\begin{array}{r}-5.1 \\
(5.3)\end{array}$ & $\begin{array}{l}-0.7 \\
(3.7)\end{array}$ \\
\hline LOSS & $\begin{array}{l}-9.1^{* * *} \\
(2.0)\end{array}$ & $\begin{array}{l}-8.4^{* * *} \\
(2.9)\end{array}$ & $\begin{array}{l}-6.1^{* * *} \\
(2.0)\end{array}$ & $\begin{array}{l}-44.0^{* * *} \\
(6.0)\end{array}$ & $\begin{array}{l}-26.8^{* * *} \\
(8.3)\end{array}$ & $\begin{array}{l}-33.9^{* * *} \\
(6.1)\end{array}$ & $\begin{array}{l}-24.0^{* * *} \\
(2.5)\end{array}$ & $\begin{array}{l}-20.5^{* * *} \\
(3.4)\end{array}$ & $\begin{array}{l}-21.1^{* * *} \\
(2.6)\end{array}$ & $\begin{array}{l}-57.9^{* * *} \\
(6.8)\end{array}$ & $\begin{array}{l}-37.0^{* * *} \\
(9.4)\end{array}$ & $\begin{array}{l}-50.7^{* * *} \\
(7.0)\end{array}$ \\
\hline CG_Realized $(000 \mathrm{~s})^{*}$ & & 0.02 & & & -0.09 & & & $-0.38^{*}$ & & & -0.02 & \\
\hline STŌCK_UP & & $(0.03)$ & & & $(0.09)$ & & & $(0.24)$ & & & $(0.31)$ & \\
\hline CG Realized (000s)* & & $0.22^{* * *}$ & & & 0.49 ** & & & $0.38^{* * *}$ & & & $0.48 *$ & \\
\hline STOECK_DOWN & & $(0.09)$ & & & $(0.24)$ & & & $(0.11)$ & & & $(0.27)$ & \\
\hline MKT_RĒT* & & & $-3.9^{* *}$ & & & $-7.4^{*}$ & & & -3.5 & & & -9.5 \\
\hline STOC̄K_UP & & & $(2.0)$ & & & $(4.3)$ & & & $(3.2)$ & & & $(6.6)$ \\
\hline $\begin{array}{l}\text { MKT_RET* } \\
\text { STOCK DOWN }\end{array}$ & & & $11.4^{* * *}$ & & & $33.8^{* * *}$ & & & $11.2^{* * *}$ & & & $17.3^{* *}$ \\
\hline
\end{tabular}

Notes: For columns (2), (5), (8), and (11): SELL DECEMBER ${ }_{\mathrm{i}, \mathrm{t}}=\alpha+\beta_{1} * \mathrm{GAIN}_{\mathrm{i}, \mathrm{t}-1}+\beta_{2} * \operatorname{LOSS}_{\mathrm{i}, \mathrm{t}-1}+\beta_{3} * \mathrm{CG}_{-}$Realized $_{\mathrm{t}-1} * \mathrm{STOCK}_{\mathrm{S}} \mathrm{UP}_{\mathrm{i}, \mathrm{t}-1}+$

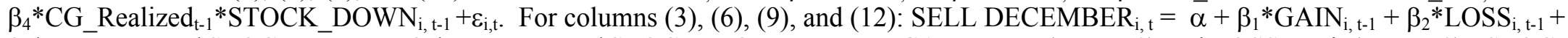

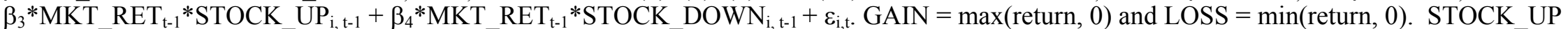
(STOCK DOWN) is an indicator variable reflecting that the stock price rose (fell) from its purchase date through the end of November. CG Realized ${ }_{\mathrm{t}-1}=$ net capital gain/loss realized via sales of stock in a taxable account during the calendar year through the end of November (through the last five trading days of December for the December - Last Week regressions). MKT RET $_{\mathrm{t}-1}=$ value-weighted CRSP capital appreciation return during the calendar year through the end of November (through the last five trading days of December for the December - Last Week regressions). All coefficients have been appropriately scaled to correspond to monthly realization rates, so that the coefficients from the month and week regressions are comparable. Standard errors (shown in parentheses) allow for heteroskedasticity as well as correlation across observations of the same household.

${ }^{* * *},{ }^{* *},{ }^{*}$ denote significance at the 1 percent, 5 percent, and 10 percent levels, respectively. 
Table 12 - Gompertz Proportional Hazards Model of Stock Sales For Large PURCHASES (AT LEAST \$10,000)

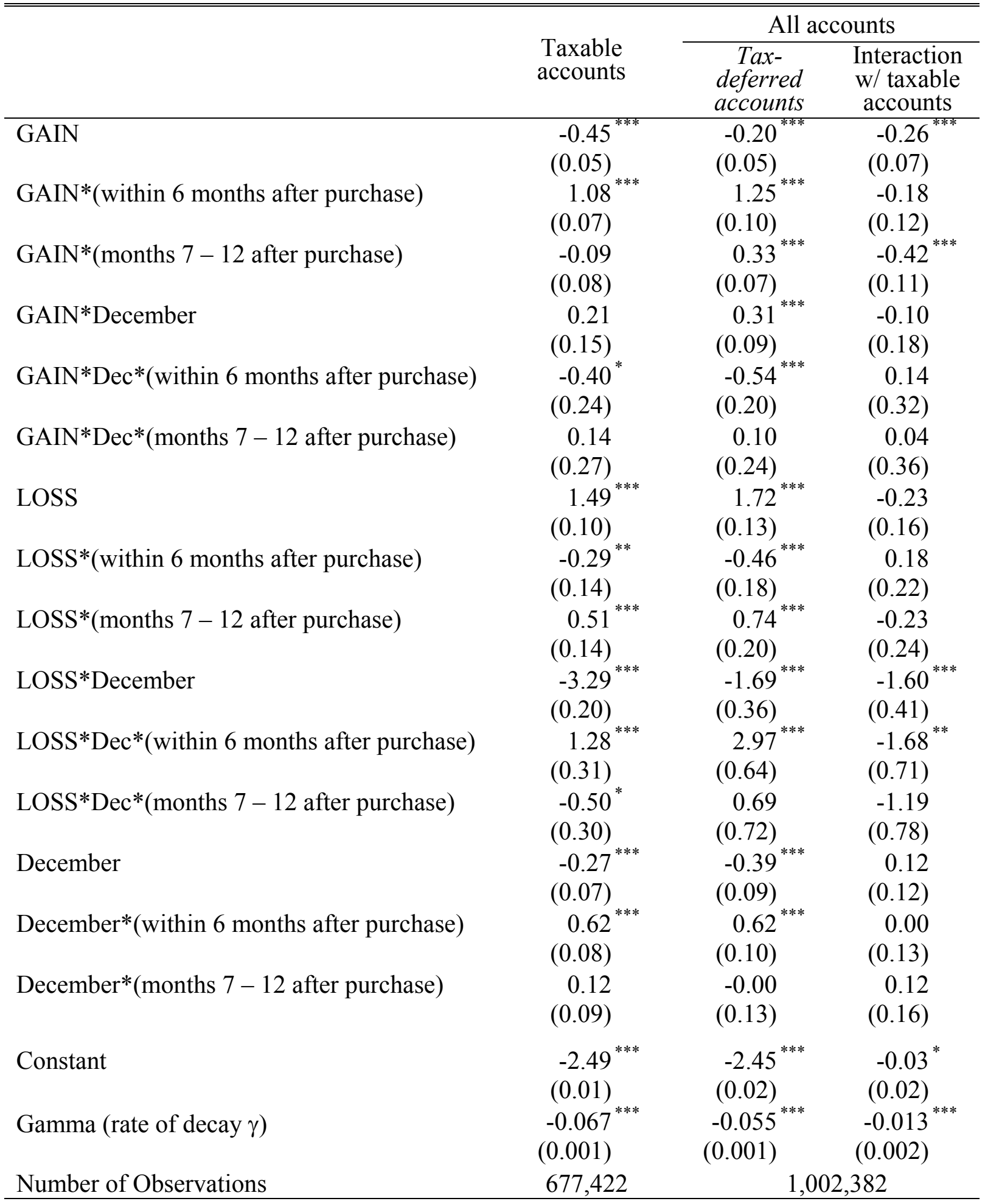

Notes: GAIN $=\max ($ return, 0$)$ and LOSS $=\min ($ return, 0$)$. Standard errors (shown in parentheses) allow for heteroskedasticity as well as correlation across observations of the same household.

${ }^{* * *},{ }^{* *},{ }^{*}$ denote significance at the 1 percent, 5 percent, and 10 percent levels, respectively. 
Table 13-Probability of Sale and Expected Holding Period for Large Stock Purchases (at Least \$10,000)

\begin{tabular}{|c|c|c|c|c|c|c|c|c|}
\hline \multirow{2}{*}{$\begin{array}{l}\text { Time period } \\
\text { since purchase }\end{array}$} & \multicolumn{2}{|c|}{$\begin{array}{l}\text { Probability of stock sold } \\
\text { Within given time period }\end{array}$} & \multicolumn{2}{|c|}{$\begin{array}{c}\text { Probability of stock sold } \\
\text { within } 5 \text { years since purchase } \\
\text { conditional on } \\
\text { having held the stock for } \\
\text { the given time period } \\
\end{array}$} & \multicolumn{2}{|c|}{$\begin{array}{l}\text { Probability of } \\
\text { no sale of stock } \\
\text { conditional on } \\
\text { having held the stock for } \\
\text { the given time period* }\end{array}$} & \multicolumn{2}{|c|}{$\begin{array}{c}\text { Expected } \\
\text { holding period* }\end{array}$} \\
\hline & taxable & tax-deferred & taxable & tax-deferred & taxable & tax-deferred & taxable & tax-deferred \\
\hline $\begin{array}{l}\text { Time } 0 \text { : } \\
\text { purchase date }\end{array}$ & NA & NA & $76 \%$ & $78 \%$ & $29 \%$ & $24 \%$ & 75 mos. & 64 mos. \\
\hline 1 month & $23 \%$ & $21 \%$ & $67 \%$ & $73 \%$ & $38 \%$ & $29 \%$ & 98 mos. & 78 mos. \\
\hline 6 months & $49 \%$ & $49 \%$ & $45 \%$ & $56 \%$ & $54 \%$ & $42 \%$ & 140 mos. & 115 mos. \\
\hline 1 year & $59 \%$ & $60 \%$ & $32 \%$ & $44 \%$ & $65 \%$ & $50 \%$ & 167 mos. & 138 mos. \\
\hline 2 years & $67 \%$ & $69 \%$ & $18 \%$ & $29 \%$ & $77 \%$ & $61 \%$ & 196 mos. & 168 mos. \\
\hline 3 years & $72 \%$ & $75 \%$ & $9 \%$ & $14 \%$ & $84 \%$ & $66 \%$ & 212 mos. & 185 mos. \\
\hline
\end{tabular}

Notes:

* The probability that the stock is never sold is estimated by the proportional hazards Gompertz model. When calculating the expected holding period of the stock, the probability of no sale is multiplied by 20 years and then added to the product of the expected holding period, conditional on a sale being made (in a probabilistic sense), and the probability of sale as estimated by the proportional hazards Gompertz model.. 
TABle 14-Propensity to RepurChase SAME STOCK IN TAXABLE ACCOUNT WITHIN ONE AND

Two Months since Sale in TAXable Accounts, For Large Stock Purchases

(AT LEAST \$10,000)

\begin{tabular}{|c|c|c|c|c|c|}
\hline \multicolumn{3}{|c|}{$\begin{array}{c}\text { Propensity to Repurchase Stock within } \\
\text { One Month since Sale }\end{array}$} & \multicolumn{3}{|c|}{$\begin{array}{c}\text { Propensity to Repurchase Stock during } \\
\text { Second Month since Sale }\end{array}$} \\
\hline $\begin{array}{l}\text { Sale with } \\
\text { Realized } \\
\text { Loss } \\
\end{array}$ & $\begin{array}{c}\text { Sale with } \\
\text { Realized } \\
\text { Gain }\end{array}$ & Difference & $\begin{array}{c}\text { Sale with } \\
\text { Realized } \\
\text { Loss } \\
\end{array}$ & $\begin{array}{c}\text { Sale with } \\
\text { Realized } \\
\text { Gain }\end{array}$ & Difference \\
\hline \multicolumn{3}{|c|}{ Sales in December } & \multicolumn{3}{|c|}{ Sales in December } \\
\hline $\begin{array}{l}4.5^{* * *} \\
(0.6)\end{array}$ & $\begin{array}{l}10.4^{* * *} \\
(0.9)^{2}\end{array}$ & $\begin{array}{l}-5.9^{* * *} \\
(1.0)\end{array}$ & $\begin{array}{l}4.0^{* * *} \\
(0.5)\end{array}$ & $\begin{array}{l}6.7^{* * *} \\
(0.7)\end{array}$ & $\begin{array}{l}-2.8^{* * *} \\
(0.8)\end{array}$ \\
\hline \multicolumn{3}{|c|}{ Sales in non-December Months } & \multicolumn{3}{|c|}{ Sales in non-December Months } \\
\hline $\begin{array}{l}8.5^{* * *} \\
(0.4)\end{array}$ & $\begin{array}{l}12.1^{* * *} \\
(0.5)\end{array}$ & $\begin{array}{l}-3.6^{* * *} \\
(0.4)\end{array}$ & $\begin{array}{l}4.9^{* * *} \\
(0.3)\end{array}$ & $\begin{array}{l}7.0^{* * *} \\
(0.3)\end{array}$ & $\begin{array}{l}-2.2^{* * *} \\
(0.3)\end{array}$ \\
\hline \multicolumn{3}{|c|}{ Difference (December - All Other Months) } & \multicolumn{3}{|c|}{ Difference (December - All Other Months, } \\
\hline $\begin{array}{l}-4.0^{* * *} \\
(0.6)\end{array}$ & $\begin{array}{l}-1.7^{*} \\
(0.9)\end{array}$ & $\begin{array}{l}-2.3^{* *} \\
(1.0)\end{array}$ & $\begin{array}{r}-0.9 \\
(0.5)\end{array}$ & $\begin{array}{r}-0.3 \\
(0.7)\end{array}$ & $\begin{array}{r}-0.6 \\
(0.9)\end{array}$ \\
\hline
\end{tabular}

Notes: Sample consists of sales of stock from January 1991 to October 1996, originally purchased for at least $\$ 10,000$.

*** ${ }^{* *},{ }^{*}$ denote significance at the 1 percent, 5 percent, and 10 percent levels. 
TABLE 15-PROPENSITY TO REPURChASE SAME STOCK IN TAXABLE AND TAX-DEFERRED

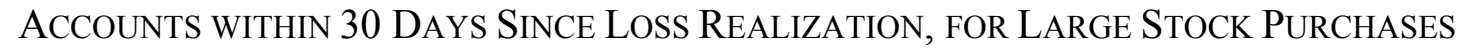
(AT LEAST \$10,000)

\begin{tabular}{|c|c|c|}
\hline & $\begin{array}{l}\text { Realization of Loss } \\
\text { in TAXABLE account }\end{array}$ & $\begin{array}{c}\text { Realization of Loss } \\
\text { in TAX-DEFERRED } \\
\text { account }\end{array}$ \\
\hline & \multicolumn{2}{|c|}{ Sales in December } \\
\hline $\begin{array}{l}\text { Purchase in Taxable Account } \\
\text { within } 30 \text { days }\end{array}$ & $\begin{array}{l}4.5^{* * *} \\
(0.6)\end{array}$ & $\begin{array}{l}1.8^{* * *} \\
(0.7)\end{array}$ \\
\hline \multirow[t]{2}{*}{$\begin{array}{l}\text { Purchase in Tax-Deferred Account } \\
\text { within } 30 \text { days }\end{array}$} & $\begin{array}{l}0.9^{* * *} \\
(0.2)\end{array}$ & $\begin{array}{l}5.7^{* * *} \\
(1.4)\end{array}$ \\
\hline & \multicolumn{2}{|c|}{ Sales in non-December Months } \\
\hline $\begin{array}{l}\text { Purchase in Taxable Account } \\
\text { within } 30 \text { days }\end{array}$ & $\begin{array}{l}8.5^{* * *} \\
(0.4)\end{array}$ & $\begin{array}{c}2.5^{* * *} \\
(0.3)\end{array}$ \\
\hline \multirow[t]{2}{*}{$\begin{array}{l}\text { Purchase in Tax-Deferred Account } \\
\text { within } 30 \text { days }\end{array}$} & $\begin{array}{l}1.4^{* * *} \\
(0.2)\end{array}$ & $\begin{array}{l}8.0^{* * *} \\
(1.2)\end{array}$ \\
\hline & \multicolumn{2}{|c|}{ Difference (December - All Other Months) } \\
\hline $\begin{array}{l}\text { Purchase in Taxable Account } \\
\text { within } 30 \text { days }\end{array}$ & $\begin{array}{l}-4.0^{* * *} \\
(0.6)\end{array}$ & $\begin{array}{r}-0.7 \\
(0.7)\end{array}$ \\
\hline $\begin{array}{l}\text { Purchase in Tax-Deferred Account } \\
\text { within } 30 \text { days }\end{array}$ & $\begin{array}{l}-0.5^{*} \\
(0.3)\end{array}$ & $\begin{array}{r}-2.4 \\
(1.5)\end{array}$ \\
\hline
\end{tabular}

Notes: ${ }^{* * *},{ }^{* *},{ }^{*}$ denote significance at the 1 percent, 5 percent, and 10 percent levels, respectively. 


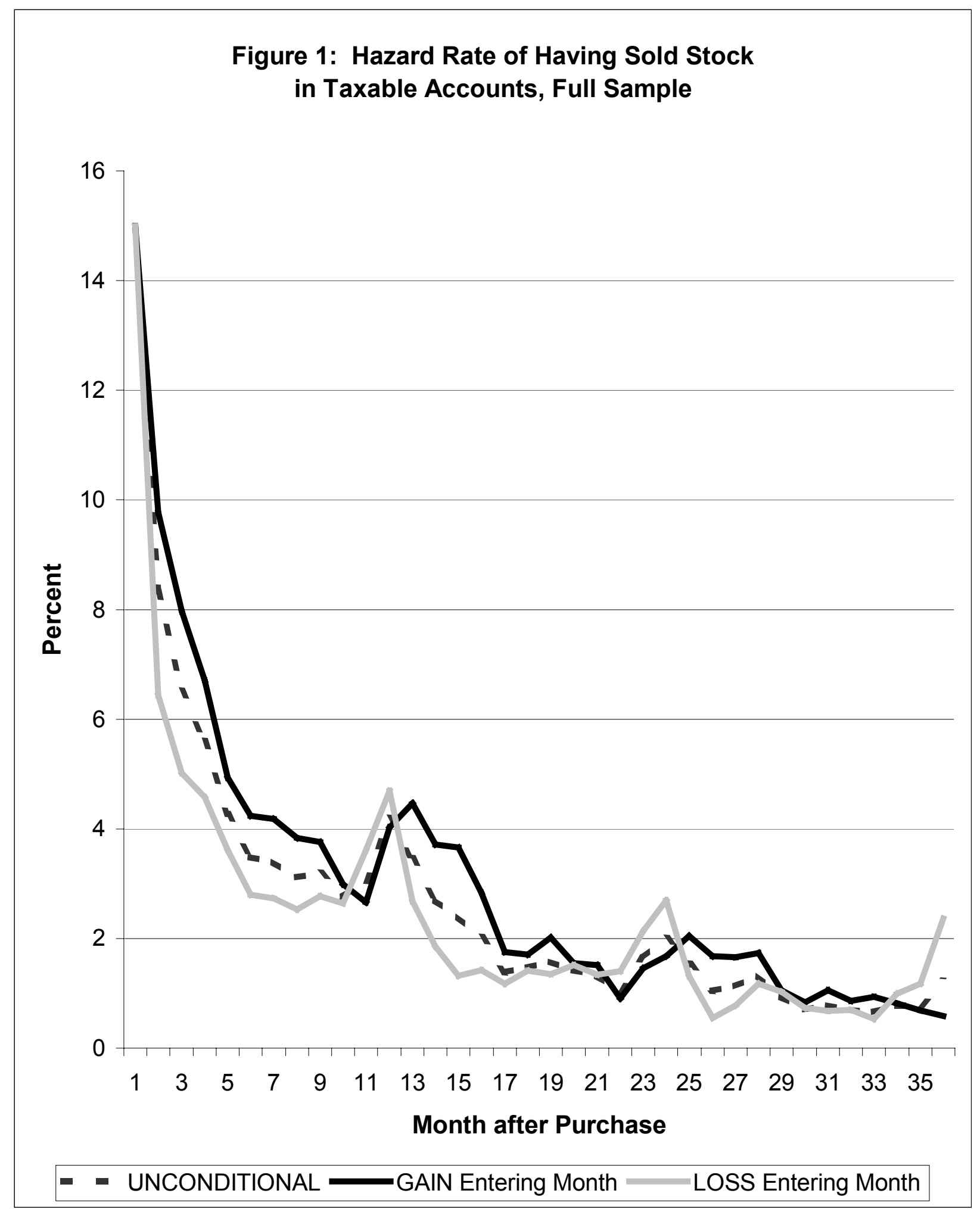

Notes: Sample is January purchases of stock 1991-96 in taxable accounts. The hazard rate for stock purchases unconditional on the stock's price performance, as well as conditional on whether the stock has an accrued capital gain or loss entering the month, is displayed. 


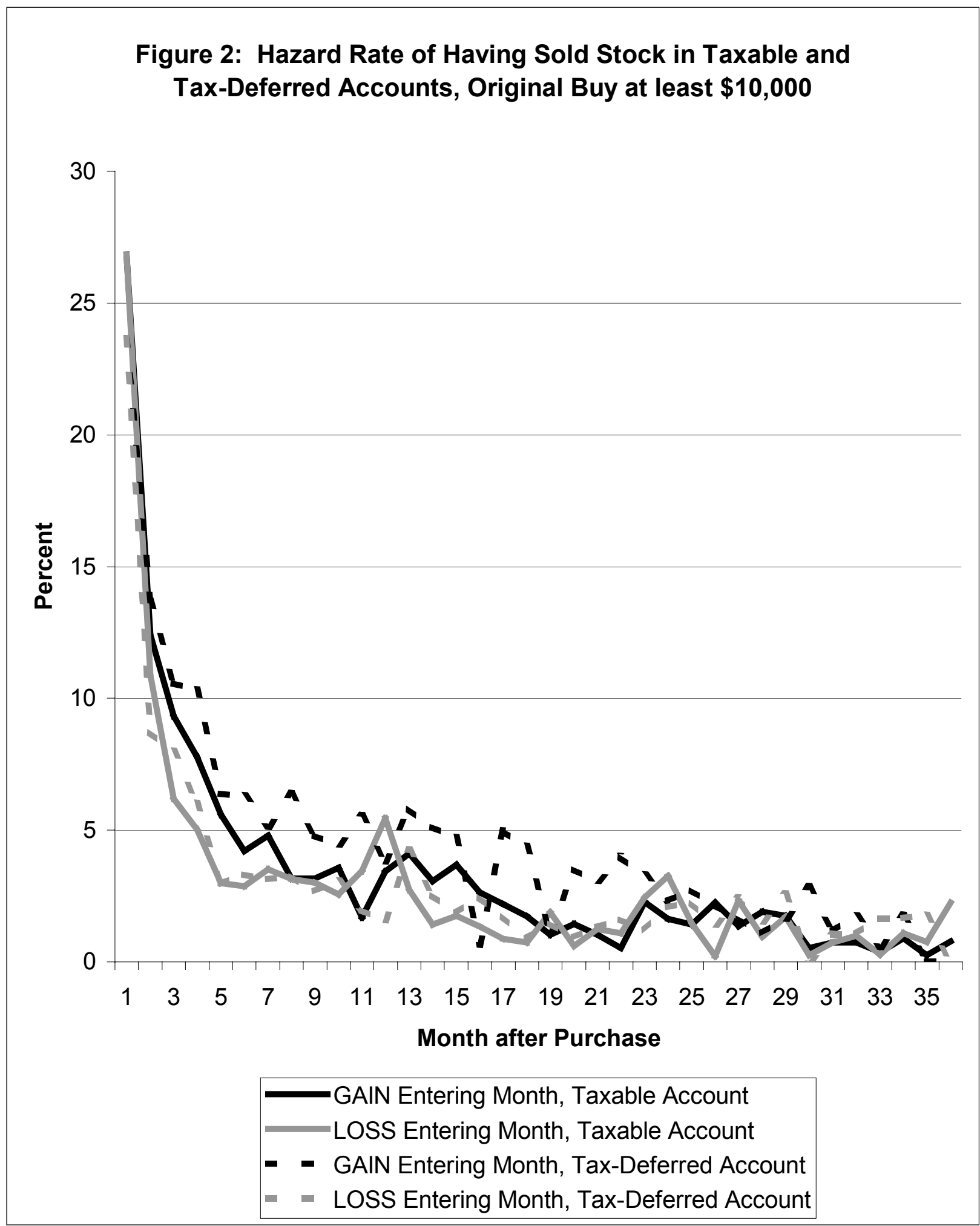

Notes: Sample is January purchases of stock of at least $\$ 10,000$ from 1991-96. The hazard rate for stock purchases conditional on whether the stock has an accrued capital gain or loss entering the month is displayed for taxable and tax-deferred accounts. 


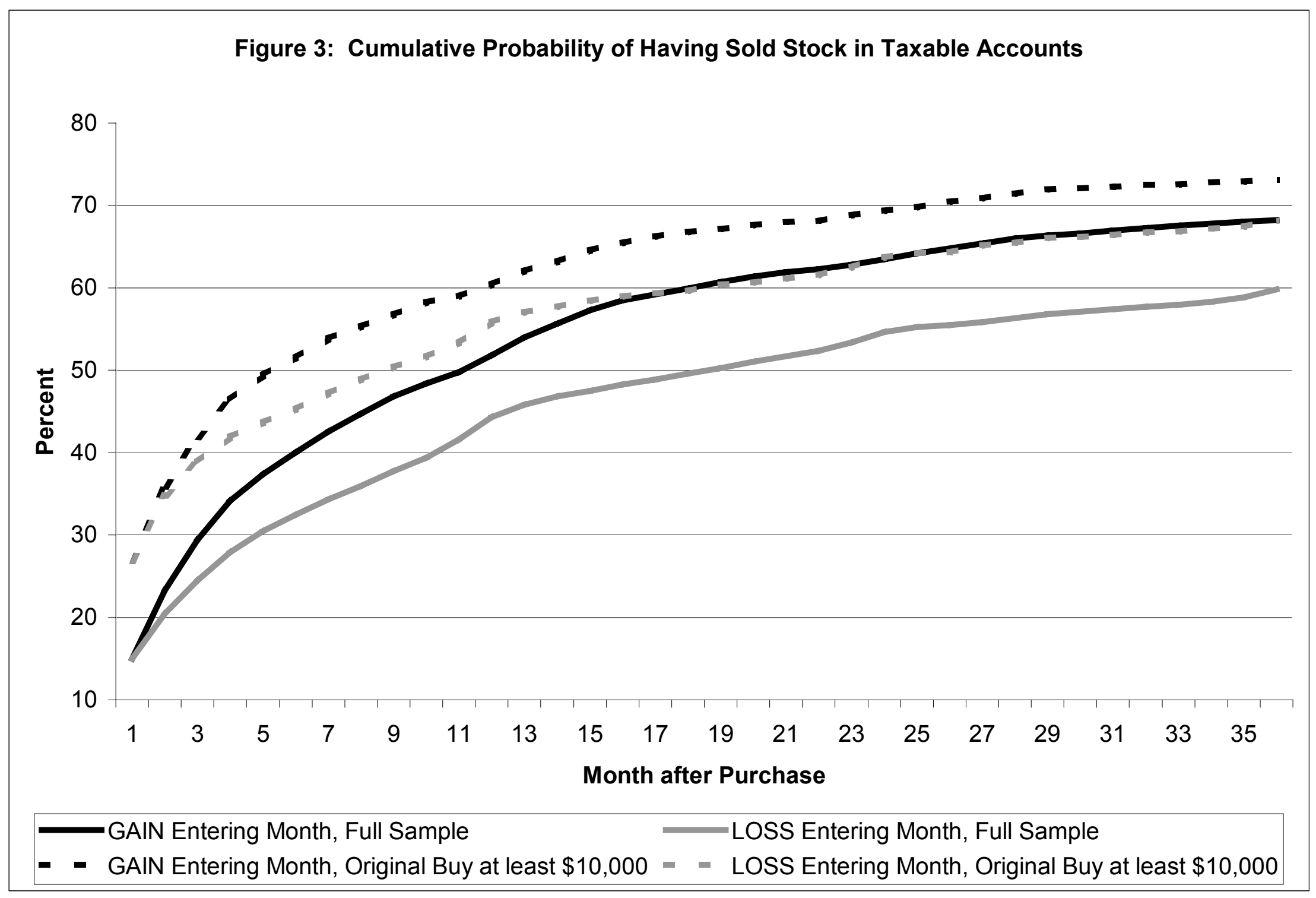

Notes: Sample is January purchases of stock 1991-96 in taxable accounts. If $h(t)$ denotes the hazard rate in month $t$, the probability that the stock is sold by the end of month $\mathrm{t}$ is $\left[1-\left(\Pi_{\mathrm{s}=1, \mathrm{t}}(1-\mathrm{h}(\mathrm{s}))\right)\right]$. 


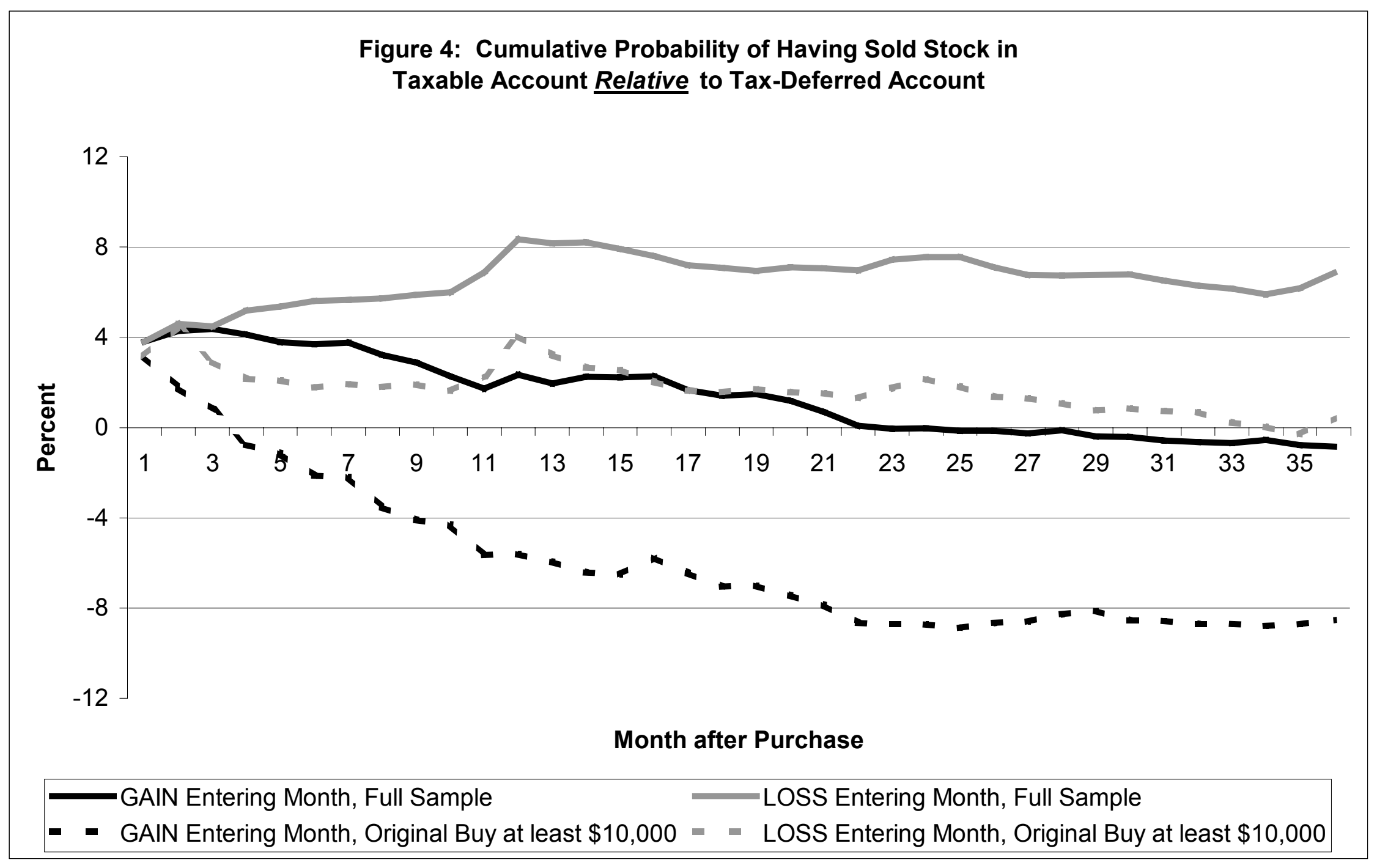

Notes: Sample is January purchases of stock 1991-96. If $\mathrm{h}(\mathrm{t})$ denotes the hazard rate in month $\mathrm{t}$, the probability that the stock is sold by the end of month $\mathrm{t}$ is $\left[1-\left(\Pi_{\mathrm{s}=1, \mathrm{t}}(1-\mathrm{h}(\mathrm{s}))\right)\right]$. Figure 4 displays cumulative probability of sale in a taxable account less that in a tax-deferred account for each month. 


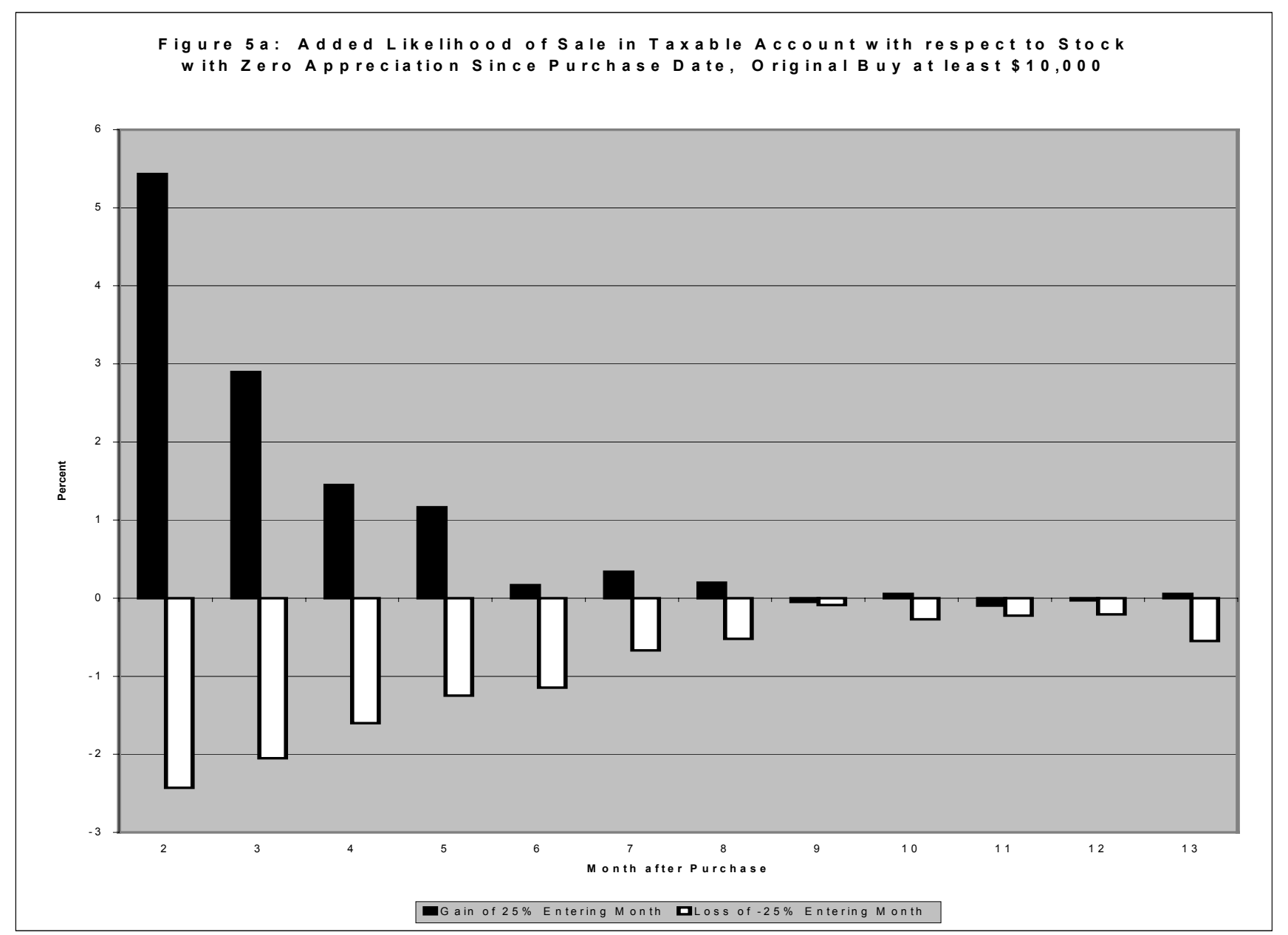

Notes: Added likelihood of selling stock with a $25 \%$ gain (loss) since purchase with respect to a stock with zero appreciation is estimated from the following regression separately for taxable and tax-deferred accounts: Sell $l_{\mathrm{i}, \mathrm{t}}=\alpha_{\mathrm{t}}+\beta_{1, \mathrm{t}}{ }^{*} \mathrm{GAIN}_{\mathrm{i}, \mathrm{t}-1}+\beta_{2, \mathrm{t}} * \mathrm{LOSS}_{\mathrm{i}, \mathrm{t}-1}$ $+\varepsilon_{\mathrm{i}, \mathrm{t}}$, where GAIN $=\max ($ return, 0$), \mathrm{LOSS}=\min ($ return, 0$)$. The added likelihood of sale is then $\beta_{1, t} * \mathrm{GAIN}_{\mathrm{i}, \mathrm{t}-1}$ or $\beta_{2, \mathrm{t}} * \mathrm{LOSS}_{\mathrm{i}, \mathrm{t}-1}$. Figure $5 \mathrm{a}$ displays the results for taxable accounts. Figure $5 \mathrm{~b}$ displays the results for taxable accounts less the results for tax-deferred accounts. 


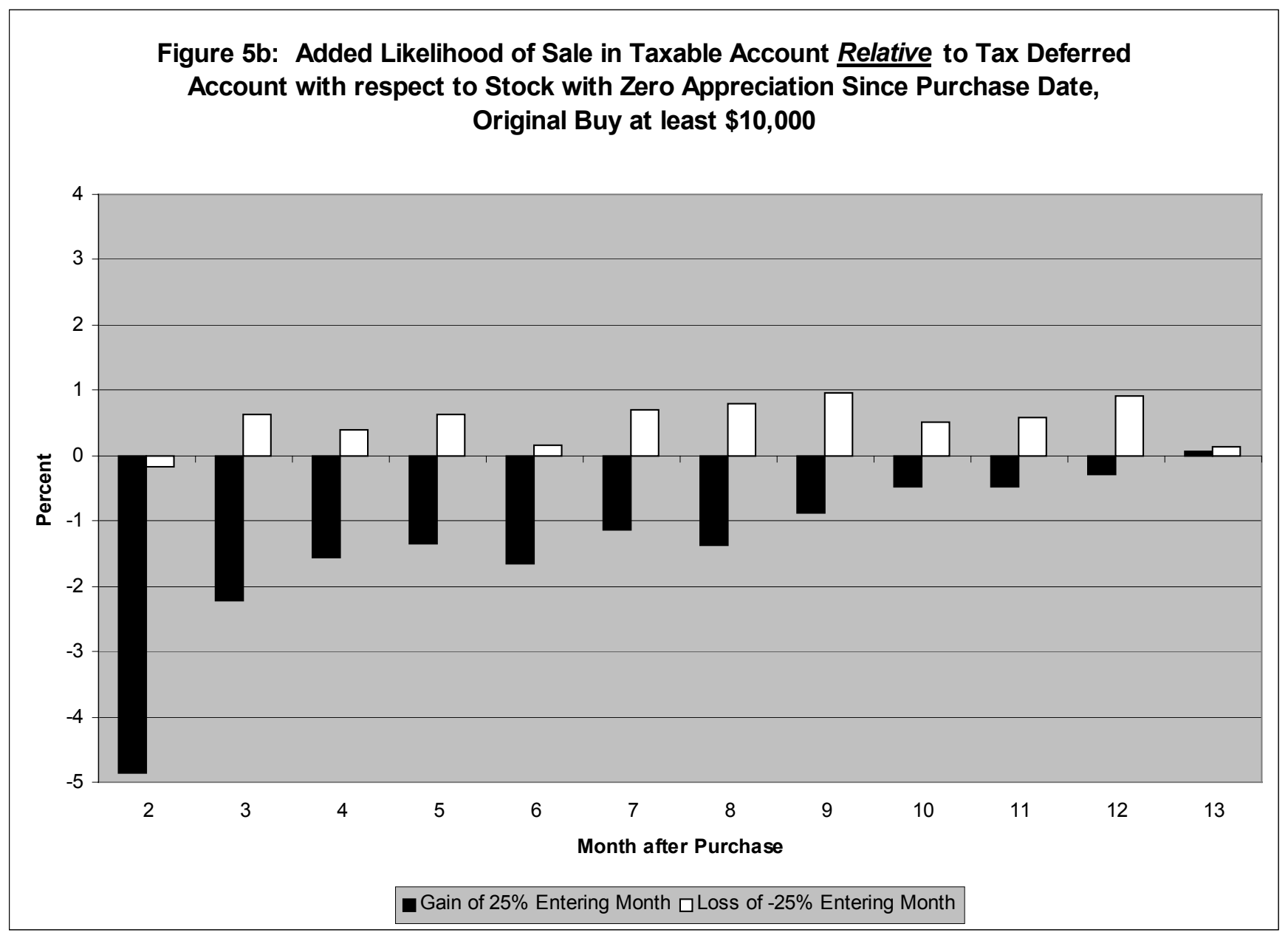

Notes: Added likelihood of selling stock with a $25 \%$ gain (loss) since purchase with respect to a stock with zero appreciation is estimated from the following regression separately for taxable and tax-deferred accounts: Sell $_{\mathrm{i}, \mathrm{t}}=\alpha_{\mathrm{t}}+\beta_{1, \mathrm{t}}{ }^{*} \mathrm{GAIN}_{\mathrm{i}, \mathrm{t}-1}+\beta_{2, \mathrm{t}} * \mathrm{LOSS}_{\mathrm{i}, \mathrm{t}-1}$ $+\varepsilon_{\mathrm{i}, \mathrm{t}}$, where GAIN $=\max ($ return, 0$)$, LOSS $=\min ($ return, 0$)$. The added likelihood of sale is then $\beta_{1, t} * \mathrm{GAIN}_{\mathrm{i}, \mathrm{t}-1}$ or $\beta_{2, \mathrm{t}} * \mathrm{LOSS}_{\mathrm{i}, \mathrm{t}-1}$. Figure $5 \mathrm{a}$ displays the results for taxable accounts. Figure $5 \mathrm{~b}$ displays the results for taxable accounts less the results for tax-deferred accounts. 

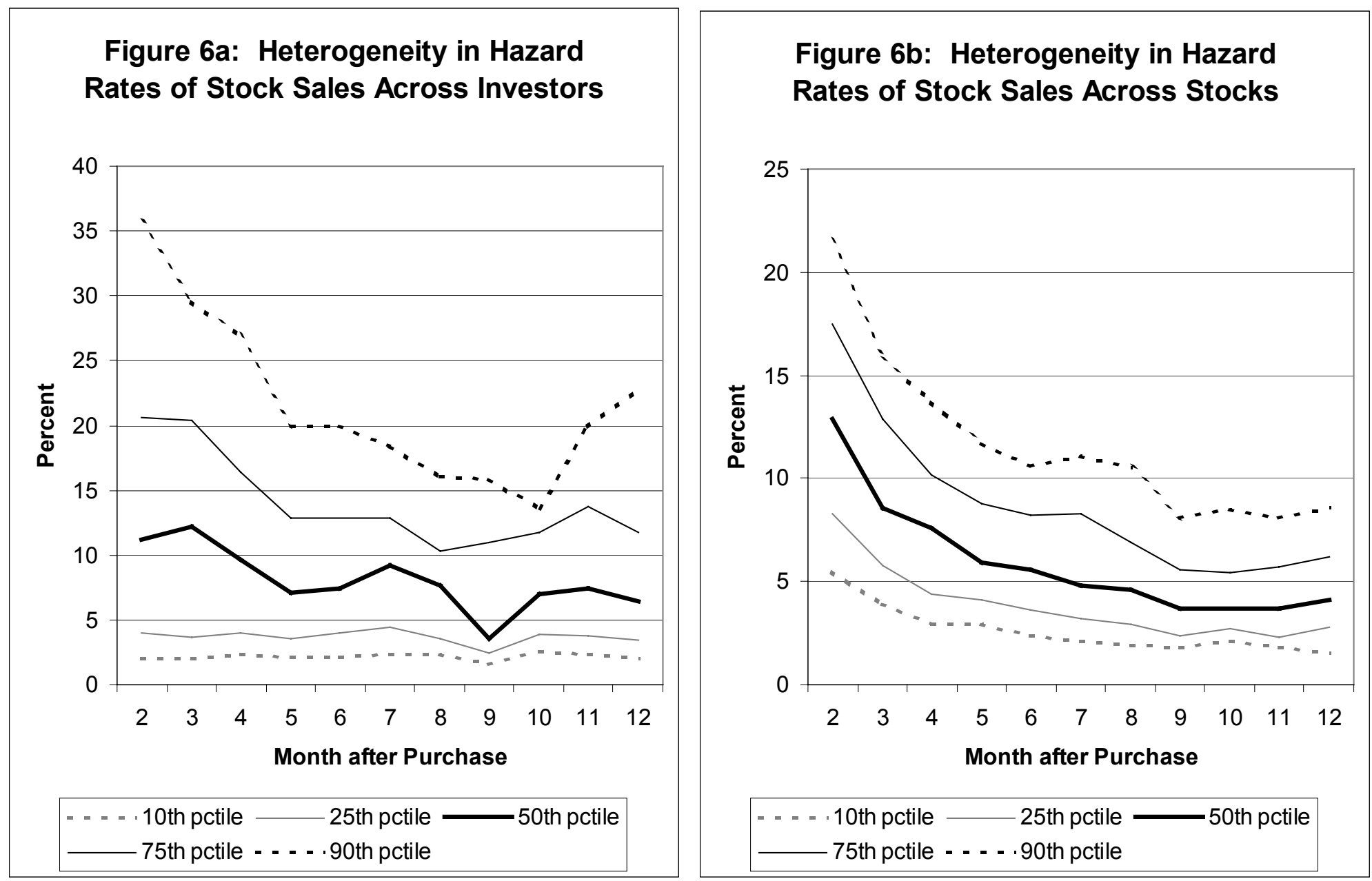

Notes: Figure 6a displays the distribution of investor-specific baseline hazard rates for households with 50 or more purchases taken from the regression estimated with investor-specific baselines for taxable accounts in Table 9. Figure 6b displays the distribution of stock-specific baseline hazard rates for stocks purchased 50 or more times, taken from the regression estimated with stock-specific baselines for taxable accounts in Table 9. 

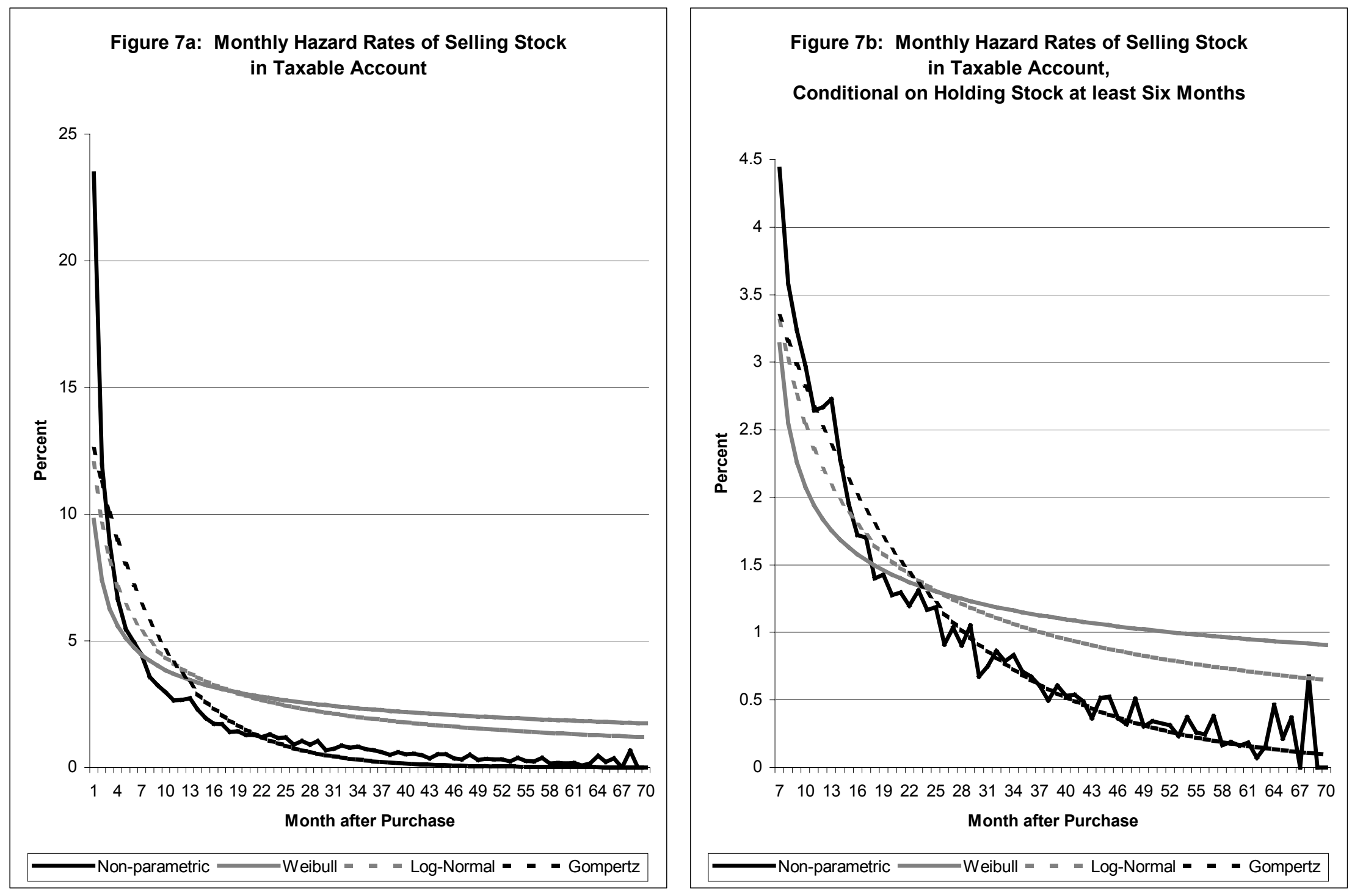

Notes: Sample is purchases of stocks in taxable accounts of at least $\$ 10,000$ from 1991-96. 